\title{
Satisfaction as a Form of Reparation for Moral Damages Suffered by Investors and Respondent States in Investor-State Arbitration Disputes
}

\section{PATRICK DUMBERRY*}

The question examined in this article is how moral damages should be remediated by arbitral tribunals in the specific context of investor-State arbitration. In other words, is the best remedy satisfaction or monetary compensation? The article first examines the issue of reparation for moral damages under general international law, and specifically the different forms that the remedy of satisfaction may take. Under international law, monetary compensation is the appropriate remedy for moral damages affecting an individual while satisfaction is the proper means of reparation for such damages caused to a State directly. The article then examines recent investor-State arbitration cases. They also show that monetary compensation is the appropriate remedy for moral damages affecting an individual or a corporation. Two recent cases (Pey Casado $v$ Chile and Lemire $v$ Ukraine) raise the question whether or not a tribunal established under a BIT could remediate moral damages suffered by a foreign investor with satisfaction (in the form of a declaration of wrongfulness) instead of monetary compensation. This issue has never been addressed in the doctrine. In our view, satisfaction is not the proper method of remediation in this context. In two other recent cases (Europe Cement $v$ Turkey and Cementownia $v$ Turkey), Turkey sought an award of monetary compensation for moral damages it allegedly suffered with regards to its 'reputation and international standing' as a result of baseless claims filed by the foreign investors. These cases raise the unprecedented issue, never addressed in doctrine, of the appropriate remedy to redress any moral damages suffered by a State in the context of international investment law. In our view, satisfaction, in the form of a declaration of wrongfulness, would be the most appropriate form of reparation in this context. This article examines the circumstances under which moral damages may occur by distinguishing investor's misconduct in the general context of its investment in the host State from those arising in the specific context of investor-State arbitration proceedings. We conclude that the issue of moral damages suffered by a State in the context of international investment law is unlikely to frequently arise and that, in any event, under most BITs, arbitral tribunals will simply not have jurisdiction over any such claims raised by a respondent State.

\footnotetext{
* Patrick Dumberry, PhD, Assistant Professor, University of Ottawa (Civil Law Section), Canada. The author wishes to thank Ms Isabel Valenta for her comments and suggestions on an earlier draft of this article. E-mail: patrick.dumberry@uOttawa.ca. This article reflects facts current as of May 2011.

(C) The Author 2012. Published by Oxford University Press. All rights reserved. For permissions, please e-mail: journals.permissions@oup.com
} 


\section{Introduction}

The concept of 'damage' in international law includes 'material' as well as 'moral' damage (also sometimes referred to as 'non-material damage'). Moral damage is an elusive concept. It is, however, not a new concept in international law and has long been recognized by international tribunals. As explained in the 1923 Lusitania case adjudicated by the United States-Germany Mixed Claims Commission, even if moral damages are 'difficult to measure or estimate by money standards' it nevertheless remains that they are 'very real' and must therefore be compensated. ${ }^{1}$ The question addressed in this article is not whether moral damages should be remediated by arbitral tribunals in the specific context of investor-State arbitration. ${ }^{2}$ The issue is how such damages should be remediated. In other words, is the best remedy satisfaction or monetary compensation? The starting point of the analysis is that the answer essentially depends on whether the injury is suffered by an individual (or a corporation) or directly by a State itself.

The article first examines the issue of reparation for moral damages under international law (Section 2). After a brief analysis of the different methods of reparation existing under international law, our attention will turn to actual case law and State practice. This analysis shows that on the one hand, satisfaction is normally the proper remedy for moral damages suffered by a State, while on the other hand, monetary compensation is the appropriate remedy for moral damages affecting an individual.

Our analysis then turns to the proper form of reparation for moral damages in the specific context of investor-State arbitration (Section 3). Until very recently, the issue had arisen in only a handful of investor-State disputes. In 2008 alone, however, three arbitration awards discussed the issue of compensation for moral damages. In one such case, Desert Line Projects LLC v Yemen, ${ }^{3}$ the Arbitral tribunal awarded US $\$ 1$ million to the claimant in compensation for moral damages arising from wrongful acts committed by the host State. This award marks the first time compensation was ever awarded for moral damages in the context of an investment treaty.

The first part (A) of this section examines case law to determine the correctness of the view generally held by writers that monetary compensation is the proper form of reparation for moral damages affecting an individual or a corporation. In this context, we will review the case of Pey Casado v Chile, where the Tribunal refused to award any monetary compensation for moral damages for lack of proof, but nevertheless observed that the amount of compensation it awarded for material damages (US\$10 million) and, in particular, its finding

\footnotetext{
${ }^{1}$ Opinion in the Lusitania Cases, US-Germany Mixed Claims Commission, 1923, UNRIAA, vol VII, 32.

2 This question was examined by the present author in: P Dumberry, 'Compensation for Moral Damages in Investor-State Arbitration Disputes' (2010) 27 Journal of International Arbitration pp 247-76.

${ }^{3}$ Desert Line Projects LLC v Yemen, ICSID (Case No ARB/05/17) Award, 6 February 2008.
} 
that Chile had breached the Spain-Chile bilateral investment treaty (BIT) should be considered as sufficient 'satisfaction' for the investors. ${ }^{4} \mathrm{~A}$ similar comment was also made by another tribunal in the 2011 case of Lemire $v$ Ukraine. $^{5}$ These two obiter dicta raise the question whether or not a tribunal established under a BIT could (or, indeed, should) remediate moral damages suffered by a foreign investor with satisfaction in the form of a declaration of wrongfulness. In other words, can satisfaction replace monetary compensation as the appropriate remedy for moral damages affecting an individual or a corporation in investor-State arbitration? To the best of our knowledge, this issue has never been addressed in doctrine.

The second part (B) of this section examines investor-State arbitration case law concerning satisfaction. The 2009 cases of Europe Cement ${ }^{6}$ and Cementownia $^{7}$ have raised the unprecedented issue of the proper remedy for moral damages suffered by a State in international investment law. In both related cases, Turkey sought an award of monetary compensation for moral damages it allegedly suffered with regards to its 'reputation and international standing' as a result of baseless claims filed by the investors. ${ }^{8}$ This unusual request by a respondent State raises a fundamental question seldom addressed in doctrine: is satisfaction the appropriate remedy to redress any moral damages suffered by a State in the context of international investment law? Also, can an arbitral tribunal award monetary compensation to a State as a form of satisfaction ('pecuniary satisfaction')? These issues also arose in the context of a 2008 State-to-State dispute between Italy and Cuba where allegations of moral damages were raised in the context of these investment-related proceedings. We will thus examine the circumstances under which any such damages may occur by distinguishing investor misconduct in the general context of its investment in the host State from those arising in the specific context of investor-State arbitration proceedings. This is also an issue that has never been closely examined by scholars.

\section{Moral Damage under International Law}

\section{A. The Different Methods of Reparation}

The well-known basic principle of reparation in international law is set out in Article 31 of the ILC Articles. It provides that a State must make full reparation for any 'injury' caused to another State by an internationally

4 Victor Pey Casado and President Allende Foundation v Chile, ICSID (Case ARB/98/2) Award, 8 May 2008.

5 foseph Charles Lemire v Ukraine, ICSID (Case No ARB/06/18) Award, 28 March 2011.

6 Europe Cement Investment E Trade SA v Turkey, ICSID (Case No ARB(AF)/07/2) Award, 13 August 2009.

7 Cementownia 'Nowa Huta' SA v Turkey, ICSID (Case No ARB(AF)/06/2) Award, 17 September 2009.

${ }^{8}$ It should be added that in Limited Liability Company AMTO $v$ Ukraine, Arbitration Institute of the Stockholm Chamber of Commerce (Case No 080/2005) Award, 26 March 2008, Ukraine also claimed compensation for moral damages based on the same grounds. 
wrongful act. ${ }^{9}$ The same provision also indicates that the concept of injury includes 'any damage, whether material or moral, caused by the internationally wrongful act of a State. ${ }^{\prime 10}$ A State must therefore provide proper reparation for all damages, including moral damages.

The concept of moral damage is admittedly vague and uncertain. In its most general and broadest meaning it is simply the opposite of material damages, ie damages that entail a financial or an economic loss. The International Law Commission (ILC)'s Commentaries to its Draft Articles on Responsibility of States for Internationally Wrongful Acts ('ILC Articles') provides the following illustration of the type of moral damages affecting an individual that can be compensated: 'non-material damage is generally understood to encompass loss of loved ones, pain and suffering as well as the affront to sensibilities associated with an intrusion on the person, home or private life. ${ }^{11}$ International human rights tribunals have also defined the concept of moral damages. ${ }^{12}$ Wittich has put forward the following comprehensive definition of moral damages:

First, it includes personal injury that does not produce loss of income or generate financial expenses. Secondly, it comprises the various forms of emotional harm, such as indignity, humiliation, shame, defamation, injury to reputation and feelings, but also harm resulting from the loss of loved ones and, on a more general basis, from the loss of enjoyment of life. A third category would embrace what could be called non-material damage of a 'pathological' character, such as mental stress, anguish, anxiety, pain, suffering, stress, nervous strain, fright, fear, threat or shock. Finally, non-material damage would also cover minor consequences of a wrongful act, e.g. the affront associated with the mere fact of a breach or, as it is sometimes called, 'legal injury'. ${ }^{13}$

To this list should be added one specific type of moral damage: namely, injury to the credit and reputation of a legal entity, such as a corporation for

\footnotetext{
${ }^{9}$ Art 31, Titles and Texts of the Draft Articles on Responsibility of States for Internationally Wrongful Acts Adopted by the Drafting Committee on Second Reading, 26 July 2001, UN Doc A/CN.4/L.602/Rev.1.ILC ('ILC Articles on State Responsibility').

${ }_{10}$ Art 31(2) (emphasis added).

11 Commentaries to the Draft Articles on Responsibility of States for Internationally Wrongful Acts Adopted by the International Law Commission at its Fifty-Third Session (2001), November 2001, Report of the ILC on the work of its Fifty-third Session, Official Records of the General Assembly, Fifty-sixth Session, Supplement No. 10 (A/56/ 10), c IV.E.2), p 252 ('ILC Commentaries'). See also, Article 28 of the 1961 Harvard Draft Convention on the International Responsibility of States for Injuries to Aliens, 15 April 1961, by reporters LB Sohn and R Baxter, (1961) 55 American Journal Of International Law 548-84: 'Damages for bodily or mental harm, for mistreatment during detention, or for deprivation of liberty shall include compensation for past and prospective: (a) harm to the body or mind; (b) pain, suffering and emotional distress (...).'

${ }_{12}$ For instance, Inter-American Court of Human Rights, Case of the 'Street Children' (Villagrán Morales et al) $v$ Guatemala, judgement, 26 May 2001. Series C No. 77, para 84: 'This non-pecuniary damage may include both the suffering and distress caused to the direct victims and their next of kin, and the impairment of values that are highly significant to them, as well as other sufferings that cannot be assessed in financial terms.'

13 S Wittich, 'Non-Material Damage and Monetary Reparation in International Law' (2004) 15 Finnish Yearbook of International Law pp 329-30 (he uses the term 'non-material' instead of 'moral' damages).
} 
instance. It is evident that the distinction between material and moral damages is blurred in some particular circumstances. ${ }^{14}$

Article 34 of the ILC Articles indicates that there are three different methods of reparation: restitution, compensation and satisfaction. The general rule under Article 35 is that a 'State responsible for an internationally wrongful act is under an obligation to make restitution' ie 'to re-establish the situation which existed before the wrongful act was committed. ${ }^{15}$ One exception mentioned in the provision is when restitution is 'not materially' 'possible.' Under the ILC Articles, compensation is the appropriate reparation measure whenever restitution in integrum is not possible. ${ }^{16}$ The only limitation to compensation as the appropriate measure of reparation is that the damage needs to be 'financially assessable'. According to the ILC, 'material and moral damage resulting from an internationally wrongful act will normally be financially assessable and hence covered by the remedy of compensation. ${ }^{, 17}$ ILC Article 37(1) refers to a third type of reparation: 'satisfaction'. The ILC Commentaries indicates that as a form of reparation for injury, satisfaction is very much an exception: '[i]t is only in those cases where those two forms [ie restitution and compensation] have not provided full reparation that satisfaction may be required. ${ }^{18}$

It is generally recognized that restitution is not the appropriate remedy for moral damages. ${ }^{19}$ The question of whether compensation or satisfaction is the proper remedy for moral damages essentially depends on whether the damage affected the State directly or through one of its nationals. This fundamental distinction is recognized by ILC's Special Rapporteur Arangio-Ruiz and by numerous authors in doctrine. ${ }^{20}$ The next section examines separately moral damages suffered by individuals (B) and by States (C).

\footnotetext{
14 As explained by S Wittich (ibid p 330), there are many instances where 'non-material damage to the individual is the inevitable consequence of, and inseparably linked to, physical damage'. For example, this is the case of some forms of physical maltreatment, personal injury or bodily harm, which may entail an economic loss that is financially assessable and should, therefore, be deemed as a 'material' damage. However, the same physical injury may also lead to other forms of emotional harm, which must be assessed as moral damage. Conversely, some 'mental' injuries (such as, humiliation or defamation for instance) may not only be purely moral and may, indeed, cause pecuniary losses (eg medical expenses). For instance, damage to the reputation of an individual or a corporation can lead to financial losses (a 'material' damage). This risk of such overlap between material and moral damage is double-counting in terms of compensation.

15 See also Factory at Chorzów (Germany v Poland), 1928 PCIf (ser A) No 17, 47 (13 September) (' $[R]$ eparation must, as far as possible, wipe out all the consequences of the illegal act and re-establish the situation which would, in all probability, have existed if that act had not been committed.').

${ }^{16}$ ILC Article 36 reads as follows: '1 The State responsible for an internationally wrongful act is under an obligation to compensate for the damage caused thereby, insofar as such damage is not made good by restitution. 2. The compensation shall cover any financially assessable damage including loss of profits insofar as it is established.'

${ }^{17}$ ILC Commentaries (n 11) p 264 (emphasis added).

18 ibid p 263.

19 C. Gray, fudicial Remedies in International Law (Clarendon Press 1987) p 15.

20 Second Report on State Responsibility, by Mr Gaetano Arangio-Ruiz, Special Rapporteur, in Yearbook ILC, 1989, vol II, pt 1, pp 1-59 (A/CN.4/425) para 8, p 4 ('Second Report on State Responsibility'): 'moral damage to the injured State and moral damage to the injured State's nationals or agents receive different treatment from the point of view of international law.'; C Dominicé, 'De la réparation constructive du préjudice immatériel souffert
} 


\section{B. Compensation is the Proper Form of Reparation for Moral Damages Suffered by Individuals}

The work of the ILC on State Responsibility makes it clear that monetary compensation is the appropriate remedy for moral damages affecting an individual. ${ }^{21}$ This is also the position adopted by authors in doctrine. ${ }^{22}$ This is because moral damages suffered by an individual are clearly 'financially assessable'. As mentioned by the ILC, 'no less than material injury sustained by the injured State, non-material damage is financially assessable and may be the subject of a claim of compensation, as stressed in the Lusitania case. ${ }^{23}$

In the past, several international tribunals, such as the Tribunal for the Law of the $\mathrm{Sea}^{24}$ different human rights bodies ${ }^{25}$ and international employment tribunals $^{26}$ have awarded compensation to individuals for moral damages. Recent examples include the United Nations Compensation Commission (UNCC) $)^{27}$ and the Ethiopian-Eritrea Claims Commission. ${ }^{28}$ Many older cases were decided by mixed claims commissions. ${ }^{29}$ One such example is the Lusitania case decided by the United States-Germany Mixed Claims Commission in 1923 involving the sinking of the British liner Lusitania by a German submarine during the First World War killing 1,198 people, including

par un État', in C Dominicé, L'ordre juridique international entre tradition et innovation; Recueil d'études (PUF, 1997), p 355; C. Gray, ibid 41; S Wittich (n 13) pp 327-29.

${ }^{21}$ ILC Commentaries (n 11) p 252, indicating that 'compensable personal injury encompasses not only associated material losses', but also includes 'non-material damage suffered by the individual'.

${ }^{22} \mathrm{~S}$ Ripinsky and K Williams, Damages in International Investment Law (British Institute Of International And Comparative Law 2008) p 308; C Gray (n 19) p 32 ff; S Wittich (n 13) p 331; S Wittich, Non-Material Damage and Its Reparation in International Law (Martinus Nijhoff Publishers, forthcoming).

${ }^{23}$ ILC Commentaries (n 11) p 252.

${ }^{24}$ For instance, The M/V Saiga (No 2) (Saint Vincent and the Grenadines $v$ Guinea), International Tribunal for the Law of the Sea, judgment of 1 July 1999, where the Tribunal included damages for injury to the crew of a ship, their unlawful arrest, detention and other forms of ill-treatment.

${ }^{25}$ See D Shelton, Remedies in International Human Rights Law (Oxford University Press 1999). Cases are discussed in: MT Parish, AK Nelson and CB Rosenberg, 'Awarding Moral Damages to Respondent States in Investment Arbitration' (2011) 29 Berkeley Journal of International Law 227.

${ }^{26}$ Cases decided by the International Labour Organization Administrative Tribunal are discussed in MT Parish and others, ibid p 227.

27 UNCC Governing Council Decision no 3 on Personal Injury and Mental Pain and Anguish, S/AC.26/1991/3 (23 October 1991) provides, inter alia that: 'compensation will be provided for non-pecuniary injuries resulting from (...) mental pain and anguish.'

${ }_{28}$ Agreement on Cessation of Hostilities between the Government of the Federal Democratic Republic of Ethiopia and the Government of the State of Eritrea, Eth.-Erit., 18 June 2000, 2138 UNTS 86; Agreement Between the Government of the Federal Democratic Republic of Ethiopia and the Government of the State of Eritrea, Eth.-Erit., 12 December 2000, 2138 UNTS 94.

${ }^{29}$ See, inter alia, Antoine Fabiani (France c Venezuela), 30 December 1896, in H. La Fontaine PM and Eisemann, Pasicrisie internationale 1794-1900: histoire documentaire des arbitrages internationaux (Brill 1997) 367; Agnes Connelly and others, 23 November 1926, US-Mexico Claims Commission, UNRIAA, vol IV, p 118; Chevreau (France v United Kingdom), 1931, UNRIAA, vol II, p 1113; Gage, U.S.-Venezuela Mixed Claims Commission, 1903, UNRIAA, vol IX, p 226; Dispute Concerning Responsibility for the Deaths of Letelier and Moffitt, decision of 11 January 1992, UNRIAA, vol XXV, pp 1-19; I.L.R., vol 88, 1992, p 727. One classic source for older cases is: M Whiteman, Damages in International Law (vol I, US Government Printing Office 1937) 350-7, 483-91, 578-91, 777-86. See also ILC Commentaries (n 11) p 253 ff; C Gray (n 19) p 33 ff. 
128 US nationals. ${ }^{30}$ Umpire Parker awarded compensation for moral damages to the relatives of deceased victims:

That one injured is, under the rules of international law, entitled to be compensated for an injury inflicted resulting in mental suffering, injury to his feelings, humiliation, shame, degradation, loss of social position or injury to his credit or to his reputation, there can be no doubt, and such compensation should be commensurate to the injury. Such damages are very real, and the mere fact that they are difficult to measure or estimate by money standards makes them none the less real and affords no reason why the injured person should not be compensated therefore as compensatory damages, but not as a penalty. ${ }^{31}$

\section{Satisfaction is the Proper Remedy for Moral Damages Suffered by States}

There are some internationally wrongful acts that may directly affect or injure a State with respect to its honour, dignity and prestige. One may think, for instance, of insults to State symbols, such as the national flag, or to a violation of territorial integrity, a violation of the premises of embassies and consulates, an attack on ships and aircrafts, or an attack on heads of State or diplomatic/ consular representatives. ${ }^{32}$ These are examples of moral damages that are distinct from the sort typically suffered by individuals. ${ }^{33}$ The ILC explains that satisfaction is the appropriate remedy for 'those injuries, not financially assessable, which amount to an affront to the State. ${ }^{34}$ In other words, satisfaction has been considered by many international juridical bodies as the proper mean of reparation for non-material injury caused directly to a State. This is also the position supported by several writers ${ }^{35}$ as well as that of ILC's Special Rapporteur Arangio-Ruiz. ${ }^{36}$

30 Lusitania Cases (n 1) p 32.

31 ibid p 40.

32 ILC Commentaries (n 11) pp 264-5.

33 Second Report on State Responsibility (n 20) para 14, pp 5-6 ('the 'moral' damage to the State so described is in fact distinct both from the material damage to the State and, in particular, from the 'private' moral damage to nationals or agents of the State. This 'moral damage to the State' notably consists, on the one hand, in the infringement of the State's right per se and, on the other, in the injury to the State's dignity, honour or prestige'). The issue is examined in: S Wittich, (n 13) p $336 \mathrm{ff}$.

${ }^{34}$ ILC Commentaries (n 11) p 264, see also at p 244. Satisfaction is analysed in doctrine by, inter alia, these writers: C Dominicé (n 20) pp 349-65; F Przetacznik, 'La responsabilité internationale de l'Etat à raison des préjudices de caractère moral et politique causés à un autre Etat' (1974) 78 Revue Générale De Droit International Public 917; C Barthe-Gay, 'Réflexions sur la satisfaction en droit international', 49 Annuaire français de droit international, 2004, pp 105-28; Pierre André Bissonnette, La satisfaction comme mode de réparation en droit international (Geneva, 1952); E Wyler and A Papaux, 'The different forms of reparation: satisfaction' in J Crawford, A Pellet and S Olleson (eds) The Law of International Responsibility (OUP 2010) pp 623-37.

${ }^{35}$ S Wittich (n 13) pp 360-1 ('non-material damage suffered by the State directly is not covered by compensation but by satisfaction'). He argues that 'the lack of practice and the controversies in doctrine indicate that monetary payments are at present not an available remedy for non-material damage to the State. But at the same time it must be emphasised that the availability of such monetary payments should not be ruled out a priori $(\ldots)_{36}^{\prime}(\mathrm{p} 367)$.

${ }_{36}$ Second Report on State Responsibility (n 20) para 136. 
Authors sometimes distinguish between the term 'moral damages' stricto sensu, which is aimed at remediating an offence directed at a State's sovereign dignity or honour, and the other related concept of 'legal damage'. This last expression concerns the 'mere violation of a legal right or with the non-material injury inherent in any breach of the law'. ${ }^{37}$ Support in case law for such distinction is mixed. ${ }^{38}$ Although such distinction may have some importance on the actual form of satisfaction (a point examined below), the present paper uses the term moral damage in its general sense, ie encompassing the notion of 'legal' damage. ${ }^{39}$

\section{(i) The different forms of satisfaction}

The aim of satisfaction is to condemn the responsible State in order to appease the injured State. ${ }^{40}$ The ILC Commentary makes it clear, however, that 'satisfaction is not intended to be punitive in character, nor does it include punitive damages' ${ }^{41}$ What are the different forms of satisfaction? ${ }^{42}$ Article 37(2) of the ILC Articles indicates that 'satisfaction may consist in an acknowledgement of the breach, an expression of regret, a formal apology or another appropriate modality.' As explained in the ILC Commentary, 'the appropriate form of satisfaction will depend on the circumstances and cannot be prescribed in advance'. ${ }^{43}$ The only 'limit' to satisfaction is mentioned at Article 37(3) of the ILC Articles: it 'shall not be out of proportion to the injury and may not take a form humiliating to the responsible State.' There are four main forms of satisfaction.

The first form of satisfaction is for the responsible State to simply apologize or to officially express regrets for the commission of the wrongful act. ${ }^{44}$ One classic

${ }^{37}$ E Fasoli, 'Declaratory Judgments and Official Apologies as Forms of Reparation for the Non-Material Damage Suffered by the State: the Djibouti-France Case' (2008) 7 The Law and Practice of International Courts and Tribunals p 182; A Tanzi, 'Is Damage a Distinct Condition for the Existence of an Internationally Wrongful Act?' in M. Spinedi, B. Simma (eds), United Nations Codification of State Responsibility (Oceana, 1987) p 21.

${ }^{38}$ In support: Certain Questions of Mutual Assistance in Criminal Matters (Djibouti v France), Judgment of 4 June 2008, ICf Reports 2008, para 204. This is the position of E Fasoli, ibid pp 188-91. Not in support of this distinction: Rainbow Warrior Award of 1990 (n 91) stating 'This damage is of a moral, political and legal nature, resulting from the affront to the dignity and prestige not only of New Zealand as such, but of its highest judicial and executive authorities as well' (para 110, emphasis added).

39 B Bollecker-Stern, Le préjudice dans la théorie de la responsabilité internationale (Pedone 1973) p 33-34, 49; S. Wittich (n 13) pp 347-50.

${ }^{40}$ C Barth-Gay (n 34) p 123 ('la condamnation du comportement de l'État responsable est au cœur de la satisfaction qui représente toujours une sanction morale').

${ }^{41}$ ILC Commentaries (n 11) p 268.

42 This is discussed in E Wyler and A Papaux (n 34) p 629 ss.

43 ILC Commentaries (n 11) p 265.

44 ILC Commentaries (n 11) p 267. In doctrine on the issue of apology: M Awart, 'Sorry Seems to Be the Hardest Word: Apology as a Form of Symbolic Reparation' (2008) 24 South African Journal on Human Rights 50-70; RB Bilder, 'The Role of Apology in International Law and Diplomacy' (2006) 46 Virginia Journal of International Law 433-73; A Watts, 'The Art of Apology', in Maurizio Ragazzi (ed) International Responsibility Today: Essays in Memory of Oscar Schachter (Brill 2005) 107-16; HK Josephs, 'The Remedy of Apology in Comparative and International Law: Self-Healing and Reconciliation' (2004) 18 Emory International Law Review 53-84; M Gibney and E Roxstrom, 'The Status of State Apologies' (2001) 23 Human Rights Quarterly 911. 
example is the SS 'I'm Alone' case (discussed below). ${ }^{45}$ A second form of satisfaction is for a State to punish the agent or person responsible for the act. Article 45(2) of the 1996 Draft ILC Articles expressly recognized that 'in cases where the internationally wrongful act arose from the serious misconduct of officials or from criminal conduct of officials or private parties' satisfaction can take the form of 'disciplinary action against, or punishment of, those responsible'. ${ }^{46}$ While Article 37(2) of the final 2001 ILC Articles does not specifically mention this form of satisfaction, it is referred to in the ILC Commentary. ${ }^{47}$

Finally, one of the most common forms of satisfaction is when a juridical body makes a declaration on the wrongfulness of an act committed by a State. ${ }^{48}$ As explained by the Permanent Court of Arbitration in the 1913 case of Manouba, in cases in which a Power has allegedly failed to fulfil its obligations, whether general or specific, towards another Power, a finding to this effect, particularly in an arbitral award, already constitutes a serious sanction'. ${ }^{49}$ Recently, such declarations have become the most prominent form of satisfaction..$^{50}$ It is the one adopted in older ICJ cases, such as the Corfu Channel case, ${ }^{51}$ as well as recent ones like the Arrest Warrant case, ${ }^{52}$ the Bosnian Genocide case ${ }^{53}$ and the case of Certain Questions of Mutual Assistance in Criminal Matters. ${ }^{54}$ It has been argued that a judicial declaration of the unlawful character of an act is the appropriate form of

\footnotetext{
45 SS 'I'm Alone' (Canada v United States), UNRIAA, vol III, p 1618. See also: Rainbow Warrior Arbitration, Secretary-General's Ruling of 6 July 1986 (n 83).

${ }_{46}$ Text of the Draft Articles on State Responsibility Adopted by the Commission on First Reading, 1996, Report of the ILC on the Work of its Forty-eighth Session, 6 May-26 July 1996, General Assembly Official Records, Fifty-first Session Supplement No 10, UN Doc A/51/10, c III, in Yearbook ILC, 1996, vol II (Part Two), pp 58-65.

47 ILC Commentaries (n 11) p 263 ('disciplinary or penal action against the individuals whose conduct caused the internationally wrongful act').

${ }^{48}$ L Migliorino, 'Sur la declaration d'illiceité comme forme de satisfaction: à propos de la sentence arbitrale du 30 avril 1990 dans l'affaire du Rainbow Warrior' (1992) 96 Revue Générale De Droit International Public 61.

49 Affaire du Manouba (France v Italy), UNRIAA, vol XI, pp 463-79; Affaire du Carthage (France v Italy), UNRIAA, vol XI, pp 449-61. Several other cases are discussed in: Second Report on State Responsibility (n 20) p $33 \mathrm{ff}$.

${ }^{50}$ C Gray (n 19) p 45. See also: P Reuter, Droit international public (6th edn, PUF 1983) p 268. I Brownlie, Principles of Public International Law (4th edn, Clarendon Press 1990) p 460.

${ }_{51}$ Corfu Channel (United Kingdom v Albania), judgment of 9 April 1949, Merits, ICf Reports 1949, p 4, p 35.

52 Arrest Warrant of 11 April 2000 (Democratic Republic of the Congo v Belgium), Judgment of 14 February 2002, ICf Reports 2002, p 3, paras 11, 75.

53 The Application of the Convention on the Prevention and Punishment of the Crime of Genocide (Bosnia and Herzegovina v Serbia and Montenegro), Judgment of 26 February 2007, ICf Reports 2007, paras 462, 471. The Court found that Serbia, with regard to the acts of genocide committed in Srebrenica, had breached the obligation, set out in Article I of the 1948 Genocide Convention, to prevent genocide. For the Court, a mere declaration of Serbia's responsibility for not preventing the genocide was in itself appropriate satisfaction.

${ }^{54}$ Certain Questions of Mutual Assistance in Criminal Matters (Djibouti v France), Judgment of 4 June 2008, ICf Reports 2008, para 204: 'The Court determines that its finding that France has violated its obligation to Djibouti under Article 17 [of the Convention on Mutual Assistance in Criminal Matters between France and Djibouti of 27 September 1986] constitutes appropriate satisfaction.' The Court also found that the summons addressed to the Djiboutian Head of State did not violate his immunity from criminal jurisdiction (para 171) but nevertheless added that France should have apologized for failing to act in accordance with courtesy due to a Head of State (paras 172-73). This reference to an apology does not appear in the operative paragraph of the Court's finding. In doctrine: E Fasoli (n 37) pp 177-92.
} 
reparation especially for the 'legal' damage component of any moral damage suffered by a State. ${ }^{55}$

A fourth form of satisfaction (pecuniary satisfaction) will be examined in the next section. The ILC Commentaries explains that these are just some examples of the different possible 'modalities' of satisfaction. The ILC enumerates other forms such as an 'inquiry into the causes of an accident resulting in harm or injury', 56 'a trust fund to manage compensation payments in the interests of the beneficiaries', ${ }^{57}$ and giving assurances or guarantees of non-repetition. ${ }^{58}$

\section{(ii) Monetary compensation as a form of satisfaction (pecuniary satisfaction)}

A much more controversial form of satisfaction is monetary compensation, also known as 'pecuniary satisfaction'. 59 While this form of satisfaction is not mentioned at Article 37(2) of the ILC Articles, it was expressly recognized at Article 45(2) of the 1996 Draft ILC Articles which indicated that satisfaction could take the form of 'nominal damages' ${ }^{60}$ Although the final text of the ILC Articles adopted in 2001 does not specifically refer to 'pecuniary satisfaction', its Commentary mentions 'an award of symbolic damages for non-pecuniary injuries' as one of the appropriate form of satisfaction. ${ }^{61}$ Pecuniary satisfaction is also generally recognized in doctrine. ${ }^{62}$

In cases of pecuniary satisfaction, the amount awarded by a tribunal is not 'purely compensatory', ie it is not aimed at compensating a State for the actual damage suffered. Such compensation therefore clearly differs from the remedy of compensation as reparation by equivalent. ${ }^{63}$ As a form of satisfaction, monetary payment serve a different function from monetary compensation proper: it provides a symbolic amount of money to remedy a violation to a

${ }^{55}$ E Fasoli ibid p 182.

56 ILC Commentaries (n 11) p 263.

57 ibid p 265. In its 1990 Award, the Arbitral Tribunal in the Rainbow Warrior case (n 91) recommended that France contribute US $\$ 2$ million to a fund to be established to promote close and friendly relations between the citizens of the two countries (paras 126-7). This form of satisfaction is described by C Dominicé (n 20) pp 363-64 as 'réparation constructive'.

${ }^{58}$ This is discussed in C Barth-Gay (n 34) pp 118-22.

59 This issue is discussed by C Gray (n 19) pp 43-4; S Wittich (n 13) p 351 ff.; C. Barth-Gay (n 34) p $113 \mathrm{ff}$

60 Text of the Draft Articles on State Responsibility Adopted by the Commission on First Reading, 1996 (n 46). The provision also added that 'in cases of gross infringement of the rights of the injured State, damages reflecting the gravity of the infringement.'

${ }^{61}$ ILC Commentaries (n 11) p 266.

62 C Dominicé (n 20) p 359 ('la compensation pécuniaire du préjudice immatériel est une forme que peut prendre la satisfaction') ('le versement d'une somme d'argent à l'Etat lésé constitue l'un des éléments figurant dans la panoplie des instruments satisfactoires', p 360). For him, 'C'est l'intensité du préjudice immatériel qui varie considérablement d'un cas à l'autre, mais en tout état il n'est pas quantifiable, de sorte que l'on voit mal comment une compensation pécuniaire (...) pourrait constituer une réparation par équivalence. Il s'agit d'autre chose, et l'on voit sans doute que l'on est sur le terrain de la satisfaction.' (pp 359-60). It should be noted that Dominice changed his opinion on the issue when compared to its earlier writing on the topic (C. Dominice, 'La satisfaction en droit des gens', in Melanges Georges Perrin (Payot 1984) 150. Several other authors are referred to in Second Report on State Responsibility (n 20) para 107.

${ }^{63}$ ILC Commentaries (n 11) p 245 (indicating that compensation proper is 'intended to offset, as far as may be, the damage suffered by the injured State as a result of the breach'). 
State's honour and dignity. ${ }^{64}$ This is because satisfaction is concerned with a non-material injury that has a symbolic character 'on which a monetary value can be put only in a highly approximate and notional way. ${ }^{65}$ In fact, what matters for the injured State is not so much the actual amount awarded, which is anyway purely symbolic, but rather the recognition that a breach of law was committed. ${ }^{66}$ In other words, the aim is not to 'punish' a State, but to 'apaiser les ressentiments de l'État lésé, à titre symbolique à tout le moins'. ${ }^{67}$ Ultimately, the amount of damages awarded will depend on the gravity of the injury involved. ${ }^{68}$ For Domincé, in the case of a particularly grave breach of international law, satisfaction should, indeed, not be limited to an apology, but should also include monetary compensation. ${ }^{69}$

Although the theoretical distinction between pecuniary satisfaction and monetary compensation proper is no doubt sound as a matter of principle, it remains that it is often difficult to make in practice. This is certainly the case where the amount awarded as pecuniary satisfaction is not nominal at all but quite substantial (say US $\$ 1$ million). These inherent uncertainties have led some authors to favour abandoning the concept of pecuniary satisfaction altogether. ${ }^{70}$

\section{(iii) Few international tribunals have awarded pecuniary satisfaction}

Tribunals have almost never explicitly awarded pecuniary satisfaction to States. ${ }^{71}$ In fact, the I'm Alone case may be one of the only cases where such an award was rendered by a tribunal. ${ }^{72}$ This case involved a Canadian vessel, owned by US nationals, which had been sunk by the US Coast Guard. The United States-UK Claims Commission held that the United States should formally acknowledge the illegality of the act and apologize to Canada. It also added that 'as a material amend in respect of the wrong, the United States should pay the sum of $\$ 25,000$ ' to Canada. It has been argued by some writers that since Canada had suffered no real material damage as a result of the US actions, the amount of compensation should therefore be considered as

${ }^{64}$ C Dominicé (n 20) p 362.

${ }^{65}$ ILC Commentaries (n 11) pp 245-46.

${ }^{66}$ C Barth-Gay (n 34) p 124.

${ }^{67}$ C Dominicé (n 20) p 362.

${ }^{68}$ C Gray (n 19) pp 33-4.

${ }^{69}$ C Dominicé (n 20) p 362.

70 A critical analysis of the concept of 'pecuniary satisfaction' is found in S Wittich (n 13) pp 362-3, 367. He suggests abandoning the concept of pecuniary satisfaction. He supports instead the more general proposition that monetary compensation proper can be awarded for moral damages directly affecting a State. His conclusion ( $\mathrm{p}$ 367) is that if payments of substantial damages for non-material damage to the State are considered admissible they should be awarded under the title of compensation rather than satisfaction' because the terms pecuniary satisfaction is misleading. See also G Schwarzenberger, International Law (Stevens 1957), p 658 ('As international judicial practice permits monetary compensation to be awarded for other than material damage, it appears an unnecessary over-complication to distinguish it from pecuniary satisfaction. Whether symbolical or excessive, any award of damages is a form of monetary compensation').

${ }^{71}$ C Gray (n 19) p 431; S Wittich (n 13) pp 356-8.

72 S.S. 'I'm Alone' (Canada v United States) UNRIAA, vol III, p 1618. 
pecuniary satisfaction covering the non-material damage affecting Canada, presumably its rights as flag State of the boat. ${ }^{73}$ Others have, on the contrary, pointed out that Canada had, in fact, claimed more than US\$30,000 in compensation for expenses incurred for sinking the ship and that, the compensation awarded was actually for material losses. ${ }^{74}$

Another case often referred to is the Heirs of fean Maninat case decided in 1905 by the France-Venezuela Mixed Claims Commission. ${ }^{75}$ It involved injuries suffered by Mr Maninat, a French national living in Venezuela, which came as a result of an assault by members of the Venezuelan army. The Umpire concluded that Mr Maninat's subsequent death was caused by the wounds inflicted upon him by the soldiers. He concluded that Venezuela had breached its international law obligation to protect foreign nationals on its territory. $^{76}$ The Umpire awarded to France a sum of 100,000 francs in compensation to Mr Maninat's sister. The amount was based on her moral suffering resulting from her brother's death:

There is no evidence that she [i.e. Mr Maninat's sister] was ever dependent upon him for care or support, or that he ever rendered either, or that she was so circumstanced as to need either, or that he was of ability or disposition to accord either. Therefore it is difficult to measure her exact pecuniary loss. There exist only the ordinary presumptions attending the facts of a widowed sister and a brother of ordinary ability and affection. Some pecuniary loss may well be predicated on such conditions. For this she may have recompense. But the more important feature of this case is the unatoned indignity to a sister Republic through this inexcusable outrage upon one of her nationals who had established his domicile in the domain of the respondent Government. ${ }^{77}$

The award's last sentence has been interpreted by some writers as an example of pecuniary satisfaction insofar as the compensation awarded was also met to remediate the moral damage affecting France itself. ${ }^{78}$ Others have expressed doubt that this case is in fact an example of pecuniary satisfaction. This is because it is not entirely clear which portion of the amount awarded was actually intended for France itself rather than for its national. ${ }^{79}$ The same can be said with respect to the Arends case, where Venezuela was sentenced to pay US $\$ 100$ in pecuniary satisfaction for the detention of a Dutch ship. ${ }^{80}$ These

${ }^{73}$ C Gray (n 19) pp 43-4.

${ }^{74} \mathrm{~S}$ Wittich (n 13) p 356.

75 Heirs of fean Maninat, France-Venezuela Mixed Claims Commission, 1905, UNRIAA, vol X, p 55.

76 ibid p 79 .

77 ibid pp 81-82.

${ }^{78} \mathrm{~S}$ Wittich (n 13) p 356.

${ }^{79}$ C Gray (n 19) p 43.

80 Arends, Netherlands-Venezuelan Mixed Claims Commission, 1903, UNRIAA, vol X, pp 729-30: 'The damages consequent upon the detention of this vessel are necessarily small, but it is the belief of the umpire that the respondent Government is willing to recognize its responsibility for the untoward act of its officers under such circumstances and to express to the sovereign and sister State, with which it is on terms of friendship and commerce, its regret for such acts in the only way that it can now be done, which is through the action of this Commission by an award on behalf of the claimant sufficient to make full amends for the unlawful delay. In the 
three cases do not seem to the strongest authorities in support of the concept of pecuniary satisfaction.

In fact, the only case where pecuniary satisfaction was expressly recognized to remediate an injury suffered directly by a State is the famous Rainbow Warrior arbitration between France and New Zealand. ${ }^{81}$ The facts of this case are well-known and only need to be briefly set out here. In 1985, two agents of the French military security service sank the British-registered Greenpeace ship Rainbow Warrior berthed in the Auckland Harbour, New Zealand, killing Mr Pereira, a Dutch national. New Zealand caught the two French agents and convicted each of them to terms of 10 years of imprisonment. France provided monetary compensation to the widow of Mr Pereira in the amount of 2.3 million Francs. The issue of France's liability towards Greenpeace was brought before an arbitral tribunal sitting in Geneva which rendered its decision in 1987 awarding Greenpeace US $\$ 7.089$ million in compensation. ${ }^{82}$

After unfruitful diplomatic negotiations, France and New Zealand requested the U.N. Secretary-General, Mr Javier Pérez de Cuéllar, to render a binding ruling. ${ }^{83}$ On the issue of reparation, the Secretary-General's 'Ruling' of 6 July 1986 decided that France would offer an official apology and an acknowledgement of its breach of international law. ${ }^{84}$ It also awarded US $\$ 7$ million in compensation to New Zealand. The Ruling also held that the two officers should remain in a military facility on the Island of Hao, French Polynesia, for a period of three years and that they should be prohibited from leaving the Island 'for any reason, except with the mutual consent of the two governments'. ${ }^{85}$ By exchange of letters, the two governments concluded their agreements which incorporated the provisions of the ruling rendered by the Secretary-General.

opinion of the umpire this sum may be expressed in the sum of $\$ 100$ in gold coin of the United States of America, or its equivalent in silver, at the current rate of exchange at the time of payment, and judgment may be entered for that amount.'

${ }^{81}$ See in doctrine: M Pugh, 'Legal Aspects of the Rainbow Warrior Affair' (1987) 36 International \& Comparative Law Quarterly 655-69; C Chatterjee, 'The Rainbow Warrior Arbitration between New Zealand and France' (1992) 9 Journal of International Arbitration 17-28; L Migliorino (n 48) p 61; R Pinto, 'L'affaire du Rainbow Warrior: à propos de la sentence arbitrale du 30 avril 1990' (1990) 117 Annuaire Français De Droit International 841-96; J Wexler, 'The Rainbow Warrior Affair: State and Agent Responsibility for Authorized Violations of International Law' (1987) 5 Boston University International Law Journal 389-412; JS Davidson, 'The Rainbow Warrior Arbitration concerning the Treatment of the French Agents Mafart and Prieur' (1991) 40 International \& Comparative Law Quarterly 446-57.

${ }^{82}$ G Apollis, 'Le règlement de l'affaire du "Rainbow warrior"' (1987) 91 Revue Générale De Droit International Public pp 9-43; J Charpentier, 'L'affaire du "Rainbow warrior"' (1985) 31 Annuaire Français De Droit International 212-4 (also in (1986) 32 Annuaire Français De Droit International 873).

${ }^{83}$ Case concerning the Differences between New Zealand and France arising from the Rainbow Warrior Affair, Ruling of 6 July 1986 by the Secretary-General of the United Nations, UNRIAA, vol XIX, pp 199-221 ('Ruling').

${ }_{84}$ The Ruling indicates 'New Zealand seeks an apology. France is prepared to give one. My ruling is that the Prime Minister of France should convey to the Prime Minister of New Zealand a formal and unqualified apology for the attack, contrary to international law, on the Rainbow Warrior by French service agents which took place on 10 July 1985.' (ibid p 213).

${ }_{85}$ ibid p 214. 
In its pleadings, New Zealand argued that the attack was 'indisputably a serious violation of basic norms of international law' and 'a serious violation of [its] sovereignty'. ${ }^{86}$ The material damage actually suffered by New Zealand as a result of the sinking of the Greenpeace boat was, in reality, quite limited. ${ }^{87}$ Clearly the main element of New Zealand's claim for compensation was related to its moral damage, ie the 'violation of sovereignty and the affront and insult that that involved'. ${ }^{88}$ Thus, New Zealand explained that 'the sinking of the Rainbow Warrior led to a deep and genuine sense of public outrage in New Zealand' since '[i]t was the first time in [its] history that an act of international violence was committed by the armed forces of a foreign state in New Zealand territory. ${ }^{89}$ The Ruling has been considered in doctrine as a clear example of pecuniary satisfaction to remediate the moral injury suffered by a State. ${ }^{90}$

The implementation of the Ruling was problematic. Before the end of the three year period, France removed the two officers from the Island for different reasons (including health) without the consent of New Zealand. Since the dispute could not be solved through diplomatic channels, New Zealand submitted a claim to an arbitral tribunal. ${ }^{91}$ New Zealand claimed, inter alia, the existence of a moral damage: 'in this case there is not a purely technical breach of a treaty, but a breach causing deep offence to the honour, dignity and prestige of the State. ${ }^{92}$ Having concluded that France had breached its obligation under the agreement concerning one of the officers, the Tribunal addressed the question of the proper remedy. As so rightly summarized by one scholar, the Tribunal concluded that France 'added insult to injury'! ${ }^{33}$ The Tribunal first explained that ' $[\mathrm{u}]$ nlawful action against non-material interests, such as acts affecting the honour, dignity or prestige of a State, entitles the victim State to receive adequate reparation, even if those acts have not resulted in a pecuniary or material loss for the claimant State. ${ }^{94}$ The Tribunal

\footnotetext{
${ }^{86}$ Memorandum of the Government of New Zealand to the Secretary-General of the United Nations, ibid p 201.

${ }^{87}$ New Zealand nevertheless stated that it was 'entitled under international law to reimbursement by France of all costs which are a direct result of France's unlawful acts' (ibid p 202).

${ }_{88}$ Memorandum (n 86) ibid at p 202.

89 ibid p 202.

90 C Dominicé (n 20) pp 352-3; C Barth-Gay (n 34) p 116. Contra: S Wittich (n 13) p 357, for whom the Ruling is not at all conclusive on this matter.

${ }_{91}$ Case concerning the difference between New Zealand and France concerning the interpretation or application of two agreements, concluded on 9 fuly 1986 between the two States and which related to the problems arising from the Rainbow Warrior Affair (New Zealand v France), Award of 30 April 1990, UNRIAA, vol XX, p 217 ('Award').

92 ibid para 108, The Tribunal also added that 'New Zealand points out that the affront it suffered by the premature release of the two agents in breach of the treaty revived all the feelings of outrage which had resulted from the Rainbow Warrior incident'.

${ }_{93} \mathrm{~S}$ Wittich (n 13) p 343.

94 Award, para 109 (emphasis added).
} 
concluded in the case at hand, that France's actions caused New Zealand a moral damage:

[T] he Tribunal must find that the infringement of the special regime designed by the Secretary-General to reconcile the conflicting views of the Parties has provoked indignation and public outrage in New Zealand and caused a new, additional nonmaterial damage. This damage is of a moral, political and legal nature, resulting from the affront to the dignity and prestige not only of New Zealand as such, but of its highest judicial and executive authorities as well. ${ }^{95}$

The Tribunal rejected France's 'contention that satisfaction is the only appropriate remedy for non-material damage. ${ }^{96}$ It concluded that monetary compensation can be the proper remedy for moral damage:

[C]ompensation constituted a reparation not just for material damage-such as the cost of the police investigation-but for non-material damage as well, regardless of material injury and independent therefrom. Both parties thus accepted the legitimacy of monetary compensation for non-material damages. ${ }^{97}$

The Tribunal explained that it 'consider[ed] that an order for the payment of monetary compensation can be made in respect of the breach of international obligations involving, as in this case, serious moral and legal damage, even though there is no material damage'. ${ }^{98}$ The Tribunal therefore clearly contemplated awarding pecuniary satisfaction for the 'moral' injury suffered by New Zealand. ${ }^{99}$ However, the Tribunal decided not to make such an award because New Zealand had not requested it. The Tribunal then turned its attention to the issue of 'satisfaction by way of declarations of breach' and stated:

There is a long established practice of States and international Courts and Tribunals of using satisfaction as a remedy or form of reparation (in the wide sense) for the breach of an international obligation. This practice relates particularly to the case of moral or legal damage done directly to the State, especially as opposed to the case of damage to persons involving international responsibilities. 100

The Tribunal mentioned that satisfaction could take many various forms, one of which being 'a decision of an international tribunal declaring the unlawfulness of the State's conduct. ${ }^{101}$ In this case, the Tribunal declared that: '[T]he condemnation of the French Republic for its breaches of its treaty

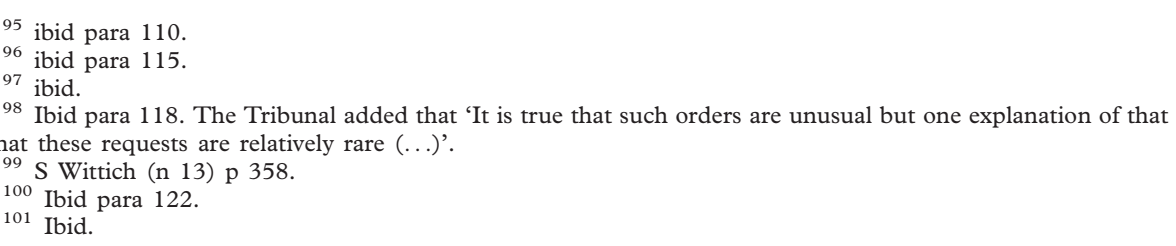


obligations to New Zealand, made public by the decision of the Tribunal, constitutes in the circumstances appropriate satisfaction for the legal and moral damages caused to New Zealand. ${ }^{, 02}$ The Ruling and the Award support the view that pecuniary satisfaction (as well as a declaration of wrongfulness) can be an appropriate form of satisfaction to remediate a moral damage affecting a State.

\section{Moral Damages in Investor-State Arbitration Disputes}

The question of moral damages has recently been raised in a number of investor-State arbitration disputes. ${ }^{103}$ Investor-State case law confirms the principle set out in the work of the ILC on State Responsibility that monetary compensation is the appropriate remedy for moral damages affecting an individual or a corporation (Section $3 \mathrm{~A}$ ) and that the proper remedy for moral damages suffered by a State is satisfaction (Section 3B).

\section{A. Compensation is the Proper Remedy for Moral Damages Suffered by Individuals and Corporations}

Investor-State arbitration awards involving claims for compensation for moral damages have been discussed elsewhere by the present author. ${ }^{104}$ Suffice it to say for the purpose of the present article that in one case, Desert Line Projects LLC $v$ Yemen, ${ }^{105}$ the Arbitral tribunal awarded the claimant an amount of US\$ 1 million in compensation. The Tribunal held that Yemen should provide compensation to a corporation for its officers' psychological suffering (in this case, the 'stress and anxiety of being harassed, threatened and detained'106) directly resulting from physical actions, ie physical duress and other related measures of coercion, interference or intimidation conducted by army/police

\footnotetext{
102 Ibid para 123 (emphasis added). The Tribunal also recommends (para 128) that the governments of France and New Zealand 'set up a fund to promote close and friendly relations between the citizens of the two countries, and that the government of the French Republic make an initial contribution equivalent to US\$2 million to that fund.'

${ }^{103}$ In doctrine P Dumberry (n 2) WM Coriell and SM Marchili, 'Unexceptional Circumstances: Moral Damages in International Investment Law', in IA Laird and TJ Weiler (eds), Investment Treaty Arbitration and International Law - vol 3 (Juris, 2010); J Cabresa, 'Moral Damages in Investment Arbitration and Public International Law', in: IA Laird and TJ Weiler (eds), Investment Treaty Arbitration and International Law - vol 3 (Juris, 2010); L. Achtouk-Spivak, 'La réparation du préjudice moral dans l'arbitrage sur le fondement de traités d'investissement : premiers développements, premiers désaccords', Cahiers de l'arbitrage, Gazette du Palais, 14-16 December 2008, pp 48-50.

${ }_{104}$ P Dumberry (n 2).

105 Desert Line Projects LLC v Yemen (n 3) In doctrine: M Alrashid, 'A Critique of Desert Line' (2008) 3 Global Arbitration Review 39-40; B Sabahi, 'Moral Damages in International Investment Law: Some Preliminary Thoughts in the Aftermath of Desert Line v. Yemen,' Festschrift, Thomas W. Wälde (Cameron, May 2009) pp 253-64; E Gaillard, 'Desert Line v. Yemen: Moral Damages' (2008) 240 New York Law Journal 3; J Burda, 'Arbitrage international et réparation des préjudices moraux: quelques enseignements de la sentence CIRDI: Desert Line Projects LCC contre République du Yemen' (2008) 48 La Revue Libanaise De L'arbitrage Arabe Et International 24-32.

${ }^{106}$ Desert Line Projects LLC v Yemen (n 3) para 179, 286.
} 
forces. ${ }^{107}$ The Tribunal also recognized that an injury to a corporation's credit, reputation and prestige is a form of moral damage that can be compensated by an award. ${ }^{108}$ The Tribunal's award marked the very first time, and thus fare the only instance, where compensation was awarded for moral damages in the context of an investment treaty. This case confirms the situation prevailing under international law whereby monetary compensation is considered as the proper remedy for moral damages affecting individuals and corporations.

For the purpose of the present discussion, three cases will be closely examined because in these awards tribunals have referred to the remedy of satisfaction. The tribunals' findings raise the unprecedented question, never addressed in doctrine, of whether satisfaction (instead of monetary compensation) can be the proper form of reparation to remediate any moral damages affecting an individual or a corporation in investor-State arbitration. The issue was for the first time addressed by an investment tribunal in 1991 in the case of LAFICO $v$ Burundi and was recently discussed in two other cases: Pey Casado v Chile (2008) and Lemire v Ukraine (2011).

\section{(i) LAFICO v Burundi}

In 1973 Libya and Burundi entered into an international treaty, namely, the Technical and Economic Cooperation Agreement. ${ }^{109}$ It was soon followed in 1975 by another agreement establishing the Libyan Arab Republic-Burundi Holding Company ('HALB'), which would invest in companies in certain sectors of Burundi's economy. HALB was a State-owned company; Libya controlled $60 \%$ of its shares, while Burundi controlled the remaining $40 \%$. In 1983, Libya transferred its shares in HALB to another Libyan State-owned company: Libyan Arab Foreign Investment Company ('LAFICO'). In 1989, Burundi broke off its diplomatic relationship with Libya and expelled all Libyan nationals, including Libyan diplomats, because they 'had been participating in activities of destabilization putting the peace and general security of the Republic of Burundi in danger.'110 As a result, LAFICO's Director-General and its Manager (both Libyan nationals) were expelled from the country. In accordance with the arbitration clause contained in the 1975 Agreement, LAFICO and Burundi referred the dispute to an arbitral tribunal.

LAFICO argued that the expulsion of these individuals and the prohibition against LAFICO to carry any activities in Burundi was contrary to the 1975 Agreement and constituted a violation of international law. It sought compensation in the amount of US $\$ 6$ million and a further US $\$ 3$ million for the pecuniary and non-pecuniary losses suffered by LAFICO and its two

\footnotetext{
107 ibid para 290.

108 ibid para 286

109 Libyan Arab Foreign Investment Company (LAFICO) v Republic of Burundi, Award, 4 March 1991, 96 ILR p 279 .

${ }^{10}$ Note verbale of the government, 5 April 1989, ibid p 283.
} 
managers. In its 1991 award, the Tribunal held that the severance of diplomatic relations between the two countries did not have any impact on the validity of the 1975 Agreement and had no effect on the continuing existence of the company HALB. The Tribunal also held that, under the circumstances of the case, the collective expulsion of all Libyans, including the two executives, was illegal under international law. The actions taken were also in breach of Article 15 of the 1975 Agreement prohibiting measures of nationalization, confiscation or any other measures limiting the ability of HALB to achieve its objective. The Tribunal awarded US $\$ 4.27$ million in compensation to LAFICO for pecuniary losses suffered as result of the unlawful acts committed by the host State.

With respect to moral damages, the Tribunal indicated that 'the actions of the government of Burundi caused serious harm to the reputation and honour of LAFICO which always behaved as a loyal partner. ${ }^{111}$ The Tribunal added that 'following current international practice', it considered that 'the finding in the award that the behaviour of Burundi constituted an unlawful act from the standpoint of international law itself constitutes appropriate satisfaction for LAFICO as a legal body'. ${ }^{112}$ The Tribunal also awarded monetary compensation (in the amount of US $\$ 97,000$ and US $\$ 82,000$ ) for losses suffered by the two executives of LAFICO as a result of their expulsions. The Tribunal included in this amount some US $\$ 10,000$ for non-pecuniary losses for the following reasons: 'the accusation against all Libyan nationals contained in the Note verbale of 5 April 1989, which implicitly and without just cause, affected [the two managers] and [their] expulsion at forty-four hours' notice caused non-pecuniary loss and prejudice to the honour of the person[s] concerned'. ${ }^{113}$

This finding confirms that monetary compensation is the appropriate remedy for moral damages affecting an individual (in this case, the company's managers). However, the award also seems to suggest that satisfaction, in the form of a declaration of wrongfulness, would be an appropriate method of remediation for a company having suffered damages to its 'reputation and honour.' At first, this finding seems contrary to international law cases examined above. The Tribunal's conclusion can, however, be explained by the specific circumstances of the case. LAFICO was a Libyan State-owned company that made business in Burundi on behalf of Libya under an international treaty. The measures of expulsion were aimed at all Libyans, including diplomats, and they specifically prohibited LAFICO to continued doing business in Burundi. It can be argued that by doing so, Burundi was targeting not only Libyans nationals and companies but also the State of Libya itself. In this context, the tarnished 'reputation and honour' resulting from the expulsion measures was as much that of Libya itself as that of its

\footnotetext{
111 ibid p 329

112 ibid (emphasis added).

113 ibid pp 329-30.
} 
State-owned company. The declaration of wrongfulness contained in the award may have been considered by the Tribunal as a proper form of satisfaction for Libya.

This case raises the larger question of whether satisfaction is the proper remedy for a State whenever one of its nationals (including corporations) is injured as a result of the commission of a wrongful act by another State. In other words, can such an indirect injury be considered as an affront to the State itself? It has been convincingly argued by writers that a State inescapably suffers damage of its own, similar to a moral wrong, when wrongful acts harm its nationals' ${ }^{114}$ One can easily imagine circumstances where a State should be entitled to satisfaction in addition to compensation given to its injured national. ${ }^{115}$ Such would be case, for instance, whenever an unlawful act specifically targets an individual precisely because of its nationality. The previously described situation of nationality-based mass expulsion is also a good example. Another would be the expropriation of assets of foreigners solely based on their nationality. In these situations, it can be argued that the wrongful act is not only directed at the person expropriated but also targeting the State of such national. ${ }^{116}$ In practice, however, States rarely claims for such 'extra' moral damages. ${ }^{117}$ Moreover, arbitral awards are typically very ambiguous regarding the nature of the damages awarded. At best, it can sometimes be deducted that a monetary award in excess of the necessary compensation for the financial loss suffered by an individual may include an element of satisfaction for the State for moral injury. ${ }^{118}$

\section{(ii) Pey Casado v Chile}

This case involves Mr Victor Pey Casado, who owned shares in a local newspaper in Chile which was confiscated by the military junta led by General Pinochet in 1973. ${ }^{119}$ After the confiscation, he fled to his native Spain. He returned to Chile in the late 1980s following the arrival of a new government promising to remedy the losses he had sustained. He was, however, unable to secure any remedies in Chilean courts and therefore commenced arbitral proceedings in 1997 under the Chile-Spain BIT claiming US $\$ 396.8$ million. $^{120}$

The Tribunal did not assess the legality of the actions which took place at the time of the coup d'état (and soon after) because the BIT had not yet entered

${ }^{114}$ EE Wyler and A Papaux (n 34) p 628. However, they believe that 'due to the generally mild character of the injury to the State, the reparation offered to the national represents in itself acceptable satisfaction for the State of nationally' and that 'the satisfaction accorded to the State thus remains hidden in the shadow of the reparation for the economic damages suffered by the national'.

${ }^{115} \mathrm{~S}$ Wittich (n 13) p 335.

116 EE Wyler and A Papaux (n 34) p 629.

117 C Gray (n 19) p 42. See also Second Report on State Responsibility (n 20) paras 9-12.

118 C Gray (n 19) pp 42-43, discussing several cases.

119 Pey Casado and President Allende Foundation v Republic of Chile, ICSID (Case ARB/98/2) Award, 8 May 2008 ('Award').

${ }_{120}$ The Salvador Allende Foundation, to which Mr Pey Casado had donated $90 \%$ of his shares, was also a party to the dispute. 
into force. The Tribunal held that it had jurisdiction under the BIT only for acts which took place after 1994. The Tribunal concluded that Chile breached the fair and equitable treatment provision contained in the Spain-Chile BIT. ${ }^{121}$ In particular, the Tribunal found that the failure by Chilean courts to render a decision on a complaint filed by Mr Pey Casado for some 7 years (from 1995 to 2002) constituted a denial of justice. ${ }^{122}$ The Tribunal awarded the Claimants US $\$ 10$ million. ${ }^{123}$

In its pleadings, the Claimants requested the Tribunal to render an award in compensation to $\mathrm{Mr}$ Pey Casado to account for moral damages. ${ }^{124}$ Over the course of the rendering of the Award the Tribunal made some interesting comments on the personal situation of Mr Pey Casado in the context of its analysis of the contentious issue whether or not the actions of Chile after the coup had resulted in him losing his Chilean nationality. The Tribunal noted the 'arbitrary and shocking behaviour' of the Chilean military authorities with respect to $\mathrm{Mr}$ Pey Casado after the coup. ${ }^{125}$ The Tribunal ultimately refused to award any compensation for moral damages to Mr Pey Casado on the ground that the Claimants failed to present sufficient proof to enable the evaluation of such damages. ${ }^{126}$ The Tribunal also made an important remark in the form of an obiter dictum. It stated that the arbitral award against Chile (awarding compensation in an amount of US\$10 million), and in particular the Tribunal's conclusion that Mr Pey Casado was the victim of a denial of justice, constitutes in itself 'substantial and sufficient moral satisfaction' for the Claimants. ${ }^{127}$

The Tribunal seems to suggest that it would have awarded no monetary compensation for moral damages to Mr Pey Casado because it considered that satisfaction, in the form of a declaration of wrongfulness, was in itself a

121 Award, para 665.

122 ibid para 659. The Tribunal also indicated that in providing compensation to individuals who were not the owners of the confiscated good and, therefore, refusing payment to $\mathrm{Mr}$ Pey Casado, Chile had 'manifestement commis un déni de justice et refusé de traiter les demanderesses de façon juste et equitable.' (ibid para 674).

123 Soon after the Award was rendered, Claimants filed an Application for Revision. The Tribunal rendered its award on 18 November 2009 dismissing the request. Chile started annulment proceedings of the Award. The case is still pending.

124 Award, para 27.

125 Ibid para 269. See also: 'M Pey Casado, à l'instar de nombreux autres citoyens considérés comme ennemis du nouveau régime issu du coup d'Etat militaire, ou rebelles, et publiquement dénoncés comme tels par ledit régime, a été contraint de chercher asile à l'étranger pour protéger sa vie et sa liberté. Il semble même que, compte tenu de sa situation personnelle et patrimoniale éminente, de son influence et de ses liens avec le Président Allende, M. Pey Casado ait été particulièrement menacé et visé par les voies de fait et mesures de la dictature militaire' (para 266, emphasis added).

126 ibid para 689.

127 ibid para 704: 'Une explication complémentaire se justifie en ce qui concerne la demande relative au dommage moral. Outre le fait que les demanderesses n'ont pas apporté de preuves permettant l'évaluation d'un tel préjudice le Tribunal arbitral estime que le prononcé de la présente sentence, notamment par sa reconnaissance des droits des demanderesses et du déni de justice dont elles furent victimes, constitue en soi une satisfaction morale substantielle et suffisante.' (emphasis added). 
proper remedy. ${ }^{128}$ Such conclusion would contrasts with above-mentioned international law cases where satisfaction is generally recognized as the proper form of reparation for moral damages affecting a State, not an individual. It is important to note, however, that the Tribunal's remark is truly an obiter dictum. Thus, the Tribunal had already concluded in the first place that the Claimants had suffered no moral damages whatsoever. The Award nevertheless raises the question whether satisfaction can, indeed, be the proper remedy for remediating actual moral damages affecting an individual (a point discussed below).

\section{(iii) Lemire v Ukraine}

This case involved a US national who had invested in Ukraine's radio broadcasting industry. The claimant, Mr Lemire, accused Ukraine's broadcasting authorities of having unfairly rejected several of his applications for new radio frequencies. In its first Award on jurisdiction and liability, the Tribunal held that Ukraine had breached the fair and equitable provision contained in the United States-Ukraine BIT and was entitled to compensation, but postponed the quantification of the damage to next phase of the arbitration. ${ }^{129}$

$\mathrm{Mr}$ Lemire also sought US $\$ 3$ million in compensation for moral damages as a result of alleged harassment measures adopted by the authorities and the stress he said to have suffered. In its first Award of 2010, the Tribunal described the allegations as follows: 'Claimant's basic line of reasoning is that, behind the individual facts of this case, an overall aim appears: the Ukrainian authorities' desire to get rid of an annoying American investor, by systematically denying any application for further frequencies, thwarting plans to create new channels, and harassing him with irregular inspections and difficulties for the renewal of his licence. ${ }^{130}$ The Tribunal first noted that 'in most legal systems' damages for moral injury can be recovered. ${ }^{131}$ It also approved the conclusion reached by the Desert Line Tribunal that investors can claim compensation for moral damages under BITs. The Tribunal described the allegations at length ${ }^{132}$ and concluded that they were 'very

${ }^{128}$ This is, for instance the position of F Latty, 'Arbitrage transnational et droit international general' (2008) 54 Annuaire Français De Droit International 502 ('Le tribunal répare donc par une mesure de satisfaction (le constat arbitral des violations) le dommage moral subi par les demandeurs, qui n'avaient du reste fourni aucune preuve de nature à permettre au tribunal de quantifier en argent leur préjudice. La structure de la phrase ('Outre le fait...') peut même laisser entendre que la fourniture de telles preuves n'aurait pas affecté la solution du tribunal. Il n'y a qu'un pas à franchir pour comprendre que les arbitres font de la satisfaction le mode de réparation idoine des préjudices moraux.').

${ }_{129}$ foseph Charles Lemire v Ukraine, ICSID (Case ARB/06/18) Decision on Jurisdiction and Liability, 21 January 2010 .

130 ibid para 449

131 ibid para 476.

132 These allegations are summarized by the Tribunal as follows: 'Claimant in essence is submitting that the National Council incurred in systemic bias against Gala Radio. Not only did the National Council reject the 200 applications made by the radio station for new frequencies, jeopardizing Gala's plans to expand its activities, but it also maliciously subjected Gala to a series of inspections, with the hidden agenda to close it down, and then in 
grave indeed. ${ }^{133}$ The Tribunal held that the question of whether these facts constituted 'exceptional circumstances' meriting awarding compensation for moral damages would have to be decided in a subsequent award on damages. ${ }^{134}$

In its 2011 final Award the Tribunal awarded the investor US $\$ 8.7$ million in compensation for his financial losses. The Tribunal also mentioned the 'exceptional circumstances' under which moral damages can be awarded:

'The conclusion which can be drawn from the above case law is that, as a general rule, moral damages are not available to a party injured by the wrongful acts of a State, but that moral damages can be awarded in exceptional cases, provided that:

- the State's actions imply physical threat, illegal detention or other analogous situations in which the ill-treatment contravenes the norms according to which civilized nations are expected to act;

- the State's actions cause a deterioration of health, stress, anxiety, other mental suffering such as humiliation, shame and degradation, or loss of reputation, credit and social position; and

- both cause and effect are grave or substantial. ${ }^{, 135}$

The Tribunal applied this test to the facts of the case and rejected the claim submitted by Mr Lemire for moral damages. The Tribunal noted that the 'excessive or disproportionate efforts which an applicant may have incurred when requesting administrative licences, by their nature, are most unlikely to give rise to moral damages, since the injury does not meet any of the three standards required for the existence of moral damages. ${ }^{136}$ For the Tribunal, Mr Lemire did not suffer 'extraordinary stress or anxiety' as a result of these efforts to obtain new radio frequencies. ${ }^{137} \mathrm{Mr}$ Lemire also claimed compensation for the disrespect and humiliation caused by the authorities' constant rejections of his applications. The Tribunal acknowledged that these recurring rejections may have caused him 'a loss of reputation', but added that 'this is not enough: the main question is to determine whether the injury inflicted is substantial.'138 For the Tribunal, 'the gravity required under the standard is not present' since the injury he suffered 'cannot be compared to that caused by armed threats, by the witnessing of deaths or

\footnotetext{
bad faith delayed the renewal of the licence, until a new regulation had come into force, which increased the renewal fee by $10^{\prime}$. (ibid para 479 ).

133 ibid para 480 .

134 ibid para 486 .

135 foseph Charles Lemire v Ukraine, ICSID (Case ARB/06/18) Award, 28 March 2011, para 333.

136 ibid para 336.

137 ibid para 337. On the issue of the repetitive inspections to Mr Lemire's business, the Tribunal 'accept[ed] that inspections by a regulator, if improperly used as tools of intimidation against regulated entities, constitute egregious behaviour and an abuse of power, which can cause extreme stress and anxiety to the supervised and result in an entitlement to be compensated for the moral damage inflicted' (ibid para 341). The Tribunal nevertheless concluded that there was no such intimidation in the present case.

138 ibid para 338.
} 
by other similar situations in which Tribunals in the past have awarded moral damages. ${ }^{139}$ The Tribunal therefore rejected the moral damages claim for lack of evidence.

In an obiter dictum, the Tribunal added that 'the acknowledgement in the First Decision [of 2010] that Ukraine has indeed breached the BIT, and the present award of substantial compensation, are elements of redress which may significantly repair $\mathrm{Mr}$ Lemire's loss of reputation. ${ }^{140}$ In its concluding remarks, the Tribunal also made a very similar comment to the effect that it 'has sympathy and understanding for the stress and anxiety which [Mr Lemire] must have felt at certain times during his long fight in the defence of his rights', but added that 'the moral aspects of his injuries have already been compensated by the awarding of a significant amount of economic compensation, and that the extraordinary tests required for the recognition of separate and additional moral damages have not been met in this case. ${ }^{141}$ These two comments suggest that the declaration of wrongfulness contained in the Award and the amount of compensation awarded for pecuniary losses were in themselves enough to compensate any sort of moral damages suffered by the investor. It is important to note, however, that those comments were truly in the form of an obiter. Thus, the Tribunal had already concluded that the investor had suffered no moral damage at all based on its application of a high threshold test of 'exceptional circumstances.'

\section{(iv) Analysis}

In our view, monetary compensation should be the only appropriate remedy for moral damages affecting an individual or a corporation. ${ }^{142}$ Satisfaction is, indeed, not the proper remedy to address such non-material injuries suffered by non-State entities. The Pey Casado and Lemire cases come to a similar conclusion. It is true that in both cases the tribunals made comments suggesting that satisfaction, in the form of a declaration of wrongfulness, could remediate any sort of moral damages suffered by an investor. However, it is noteworthy that in both cases the tribunals had already expressly indicated that the investor had suffered no such damage at all. The reasoning of the tribunals would have been, no doubt, different had they recognized the existence of actual moral damages in the first place.

In our view, a mere declaration by an arbitral tribunal recognizing the wrongfulness of acts committed by the host State is clearly an insufficient and inappropriate remedy to cover actual moral damages suffered by an investor.

\footnotetext{
139 ibid para 339.

140 ibid (emphasis added).

141 ibid para 344 (emphasis added).

142 See also S Ripinsky (n 22) p 308.
} 
This is because such moral damages are clearly 'financially assessable'. Thus, according to the ILC, moral damages suffered by an individual or a corporation 'will normally be financially assessable and hence covered by the remedy of compensation. ${ }^{143}$ International tribunals have longed abandoned the position taken by Umpire Ralston in the 1903 Di Caro case to the effect that 'no human standard of measurement exists, since affection, devotion, and companionship may not be translated into any certain or ascertainable number of bolivars or pounds sterling. ${ }^{, 144}$ Once a tribunal has identified any moral injury, there is simply no reason why such financially assessable damages should not be remediated with monetary compensation. Similarly, an official apology by a State or any similar declaration of regrets would be well below what is required to remedy the suffering resulting from a moral damage suffered by an individual or a corporation. However, nothing would prevent a tribunal from adopting some form of satisfaction in addition to (clearly identifiable) monetary compensation covering moral damages.

Finally, we believe that monetary compensation remains the appropriate remedy for moral damages affecting an individual or a corporation even if the amount allocated will admittedly often be largely symbolic. This is because quantifying a moral damage, a vague and elusive concept, is a difficult exercise that will inevitably be subject to different interpretations. Tribunals have, indeed, a great deal of flexibility to determine what amount should adequately compensate an investor for the moral damage he/she has suffered. In fact, as pointed out by two authors, 'arbitrators seem to enjoy almost an absolute discretion in the matter of determining the amount of moral damages. ${ }^{145}$ For example, little is known about how the Desert Line Project Tribunal came to the conclusion that US $\$ 1$ million was the proper amount to remediate the moral damages suffered by the investor. ${ }^{146}$ In fact, the Tribunal (quoting the Lusitania case) openly acknowledged that such damages were 'difficult to measure or estimate by money standards. ${ }^{147}$ The Tribunal only went so far as to say that the amount claimed (US $\$ 104$ million) was 'exaggerated' and that actual amount awarded was 'more than symbolic yet modest in proportion to the vastness of the project. ${ }^{148}$ Although the amount of monetary compensation to be awarded by tribunals may be largely symbolic, tribunals should nevertheless not replace it by a simple declaration of wrongfulness or by an apology.

143 ILC Commentaries (n 11) p 264. See also p 252 ('no less than material injury sustained by the injured State, non-material damage is financially assessable and may be the subject of a claim of compensation, as stressed in the Lusitania case').

${ }_{144}$ Di Caro (of a general nature), 1903, UNRIAA, Vol X, p 598.

145 S Ripinsky (n 22) p 312. See also MT Parish and others (n 25) p 233 ('moral damages will be assessed globally, without reference to proven financial losses. That is to say, the tribunal will pick a figure out of the air').

${ }_{146}$ For F Latty (n 128) p 501, this amount is 'un 'million symbolique' proche d'une mesure de satisfaction'.

147 Desert Line Projects (n 3) para 290.

148 ibid. 


\section{B. Satisfaction is the Proper Remedy for Moral Damage Suffered by States}

To date, no investment tribunal has awarded compensation to a respondent State for moral damages.

The issue was recently addressed by three arbitral tribunals. ${ }^{149}$ The reasoning of two of them suggests that the proper remedy for any moral damages suffered by a State would be satisfaction, not monetary compensation. These two cases will be examined in further detail below. ${ }^{150}$ We will first examine a 2008 State-to-State dispute between Italy and Cuba which involved allegations of moral damages.

\section{(i) Arbitration between Italy and Cuba}

An ad hoc arbitral tribunal rendered an award in 2008 in the context of an investment-related dispute between Italy and Cuba. ${ }^{151}$ Italy commenced State-to-State proceedings against Cuba invoking several violations of the Italy-Cuba BIT committed by Cuba against six Italians investors. The Tribunal held that it did not have jurisdiction over four of the six claims and rejected the allegations of wrongdoing for the other two. The Tribunal also rejected Italy's request to issue a declaration to the effect that Cuba had breached several BIT clauses, the 'letter, the spirit and the function' of the agreement as well as international norms on the treatment of aliens. ${ }^{152}$ The Tribunal also denied Italy's request to condemn Cuba to pay a symbolic $€ 1$ in compensation for these different breaches as well as for Cuba's alleged refusal to settle the dispute amicably through diplomatic channels. ${ }^{153}$

\footnotetext{
149 The issue is discussed in doctrine: MT Parish and others (n 25) pp 225-45; P Dumberry, 'How to Remediate Moral Damages suffered by a State' (Kluwer Arbitration Blog) 3 December 2009.

${ }^{150}$ Another older case in the context of a State contract is also worth mentioning: S.A.R.L. Benvenuti $\mathcal{E}$ Bonfant $v$ People's Republic of the Congo, ICSID (Case ARB/77/2) Award, 8 August 1980, (1983) 8 YB Com Arb, p 144 (also in (1993) 1 ICSID Rep., p 330). This case involved a 1973 Agreement entered into between the Government of the People's Republic of Congo (sometimes known as Congo-Brazzaville) and Benvenuti \& Bonfant srl, an Italian corporation, for the establishment of a company (Plasco Company, a joint venture $60 \%$ owned by the Government) to manufacture plastic bottles. In 1977, the Italian company commenced ICSID proceedings against Congo alleging that it had expropriated its $40 \%$ interest in the joint venture. The Tribunal concurred and awarded compensation to the investor in the amount of CFA 113.4 million. In addition, the investor also claimed some CFA 250 million for moral damages related to loss of business opportunities in Italy, loss of credit with suppliers and banks, and loss of managerial and technical personnel, following their forced departure from the investor's operations in Congo. The Tribunal held that the investor had presented insufficient proof to support these specific allegations. However, the Tribunal nevertheless decided ex aequo et bono to award compensation of less than $€ 8,000$ for moral damages on the basis that: ' $[\mathrm{I}] \mathrm{n}$ view of the measures to which Claimant has been subject and the suit that was the consequence thereof, which have certainly disturbed the activities of Claimant, the Tribunal deems it equitable to award it the amount of CFA 5,000,000 for moral damage.' (ibid 150). Congo filed a counterclaim against the investor in the amount of CFA 250 million for moral damages for, inter alia, the injury suffered as a result of being 'unjustly brought before an international court, which, for a State, is particularly serious' (Award, para 4.120). The Tribunal simply dismissed the counterclaim for the simple reason that Congo had largely prevailed in these proceedings. The Tribunal did not further examine the issue of moral damages allegedly suffered by the State.

${ }^{151}$ République d'Italie v République de Cuba, ad hoc arbitration, Final Award, 15 January 2008.

152 ibid para 244 (translation from the original French by the author).

153 ibid paras $246-47$.
} 
In the proceedings, Cuba submitted a counterclaim requesting the Tribunal to condemn Italy to 'publically and diplomatically withdrawn the allegations of wrongdoing as a form of reparation for moral damages suffered by the very fact of starting the arbitral procedure. ${ }^{154}$ Cuba therefore claimed satisfaction in the form of a declaration of wrongfulness by the Tribunal. Italy opposed such a request. The Tribunal noted that under the BIT, each party was entitled to commence arbitration proceedings and that unless such proceedings were 'abusive,' they could not be illegal and cause any compensable damages. The Tribunal rejected Cuba's claim on the ground that the proceedings were not abusive in the present case. ${ }^{155}$ It is difficult to deduct anything from the limited reasoning of the Tribunal on the issue of moral damages. The Tribunal did not specifically address the question of satisfaction as a remedy. At the most, it can be said that the Tribunal did not reject the possibility that satisfaction could be a proper remedy for moral damages suffered by a State in the context of investment-related proceedings.

\section{(ii) Europe Cement v Turkey}

Europe Cement, a Polish company, started arbitration proceedings against Turkey under the Energy Charter Treaty alleging damages for Turkey's termination of concession agreements that had been granted to two Turkish electricity corporations (Çukurova Elektrik AS ('CEAS') and Kepez Elektrik Türk AS ('Kepez')) of which Europe Cement purported to be a shareholder. ${ }^{156}$ The Tribunal declined jurisdiction over the dispute based on the claimant's inability to prove its ownership of shares in the corporations. ${ }^{157}$ The Tribunal went further and stated that the claim was in fact 'based on the false assertion of ownership of an investment' and constituted an 'abuse of process' by the claimant. ${ }^{158}$ Turkey requested the Tribunal to make a declaration that the claim was 'manifestly ill-founded and ha[d] been asserted using inauthentic documents. ${ }^{159}$ The Tribunal refused on the ground that it had no jurisdiction to hear the dispute. ${ }^{160}$

Turkey also sought monetary compensation for the moral damages it allegedly suffered to its 'reputation and international standing' ${ }^{161}$ as a result of the 'jurisdictionally baseless claim asserted in bad faith and for an improper purpose $^{, 162}$ which caused it 'intangible but no less real loss. ${ }^{163}$ For Turkey,

154 ibid para 253.

155 ibid para 254.

156 Europe Cement Investment $\&$ Trade SA v Turkey (n 6)

157 ibid para 163.

158 ibid para 175 .

159 ibid para 176. The Tribunal also noted that the Respondent had 'abandoned the use of the term 'manifestly ill-founded' without suggesting alternative language in which the declaration might be couched'.

160 ibid para 177.

161 ibid.

162 ibid.

163 ibid para 128. 
citing the Desert Line award, an amount of US $\$ 1$ million for moral damages 'would be providing a form of satisfaction, even if the award were never to be paid. ${ }^{164}$ This is a clear request of monetary compensation as a form of satisfaction (ie 'pecuniary satisfaction'). For Turkey, in the event that the amount would not be paid by the investor, satisfaction would take the form of a declaration by the tribunal acknowledging wrongfulness.

The Tribunal first noted that 'conduct that involves fraud and an abuse of process deserves condemnation', ${ }^{165}$ but added that it was a 'difficult question' to determine whether such actions 'warrant[ed] an award of damages.' ${ }^{166}$ Thus, the 'question would entail an analysis of the Tribunal's jurisdiction to hear the claim, which comes close to an ancillary claims under Article 47 of the Arbitration (Additional Facility) Rules) ${ }^{167}$ The Tribunal ultimately decided not to award any compensation since 'it [did] not consider that exceptional circumstances such as physical duress are present in this case to justify moral damages. ${ }^{168}$ In any event, for the Tribunal any 'potential reputational damage' suffered by Turkey would be 'remedied by the reasoning and conclusions set out in this Award, including an award of costs. ${ }^{, 169}$ The Tribunal ordered that the Claimant pay the Respondent its full costs for the proceedings, including legal fees (some US $\$ 3.9$ million) as well as half the arbitration costs (US $\$ 129,000)$. For the Tribunal, such an award of full costs in favour of the Respondent 'will go some way towards compensating [it] for having to defend a claim that had no jurisdictional basis and discourage others from pursuing such unmeritorious claims'. ${ }^{170}$

Essentially, this analysis supports the proposition that in this particular case, the proper remedy for any moral damage suffered by a State is satisfaction and not monetary compensation. Thus, for the Tribunal, the award's recognition that the claim was fraudulent 'provides a form of 'satisfaction' for the Respondent' for any reputational damage it may have suffered. ${ }^{171}$ In our view, the Tribunal's obiter on costs (ie that any 'reputational damage' suffered by Turkey would be remediated by an award of costs in its favour ${ }^{172}$ ) does not support the view that monetary compensation is the proper remedy for moral damages suffered by a State. Thus, in this case, the alleged moral damages suffered by Turkey resulted from the investor's misconduct which took place during the arbitration proceedings. As explained by the Tribunal, one form of sanction that can be used to deal with abuse of process committed by one party

\footnotetext{
164 ibid para 135.

165 ibid para 180 .

166 ibid para 181 .

167 ibid.

168 ibid.

169 ibid.

170 ibid para 185.

171 ibid.

172 ibid para 181 .
} 
(the investor or the host State) during the arbitration proceedings is the allocation of costs on the party in bad faith. ${ }^{173}$

\section{(iii) Cementownia v Turkey}

Cementownia 'Nowa Huta' SA ('Cementownia') is a Polish company which started arbitration proceedings against Turkey under the Energy Charter Treaty under the exact same circumstances and allegations of breach as in the above-mentioned Europe Cement case. ${ }^{174}$ The Tribunal declined jurisdiction over the dispute for lack of evidence that Cementownia ever owned any shares in the two Turkish corporations (CEAS and Kepez). The Tribunal went further and added that in any event, the claim was 'a mere artifice' to 'fabricate international jurisdiction where none should exist ${ }^{175}$ and that the claimant had 'intentionally and in bad faith abused the arbitration' by 'purport[ing] to be an investor' which constituted 'an abuse of process ${ }^{176}$ and a 'fraudulent' claim. ${ }^{177}$

The Tribunal granted Turkey's request for a 'declaration' that the Claimant filed a fraudulent claim, but refused to award compensation for alleged moral damages. Turkey had argued that 'tribunals applying international law may award to a State the remedy of satisfaction where it has suffered an intangible injury, such as injury to its reputation or prestige', and added that 'in investment treaty cases, compensation has been awarded where the injury was inflicted maliciously. ${ }^{178}$

In its analysis, the Tribunal first noted that 'there is nothing in the ICSID Convention, Arbitration Rules and Additional Facility which prevents an arbitral tribunal from granting moral damages. ${ }^{, 179}$ However, the Tribunal distinguished the present claim from the Desert Line award where the 'arbitral tribunal decided, on the basis of the obligations contained in the BIT between Yemen and Oman, in particular the obligation of security, that exceptional circumstances, such as physical duress suffered by the investor, justified the compensation. ${ }^{, 180}$ In the present case, Turkey requested compensation for moral damages 'based merely on a general principle, ie abuse of process' and not on a BIT provision. ${ }^{181}$ For the Tribunal, 'it is doubtful that such a general principle may constitute a sufficient legal basis for granting compensation for moral damages. ${ }^{182}$ The Tribunal therefore dismissed Turkey's request for compensation for moral damages.

173 ibid paras $182-86$.

174 Cementownia 'Nowa Huta' SA v Republic of Turkey (n 7).

175 ibid para 117.

176 ibid para 159.

177 ibid.

178 ibid para 165 (emphasis added).

179 ibid para 169

180 ibid.

181 ibid para 170

182 ibid. The Tribunal added that such compensation 'goes clearly beyond the general sanction of awarding the total costs on the responsible Party'. 
In any event, the Tribunal added that although 'a symbolic compensation for moral damages' could indicate the Tribunal's condemnation for the Claimant's abuse of process, in the present case however, it was more appropriate 'to sanction the Claimant with respect to the allocation of costs' (in the amount of close to US $\$ 5$ million). ${ }^{183}$ Finally, the Tribunal made a statement that seems to indicate that the 'declaration' was a proper form of reparation to Turkey: 'In any case, since the Arbitral Tribunal has already accepted the Respondent's request with respect to the fraudulent claim declaration, the Respondent's objective is already achieved. ${ }^{184}$ It is submitted that this case also supports the view that satisfaction, in the form of a declaration, is the proper remedy for moral damages suffered by a respondent State.

\section{(iv) Analysis}

We support the conclusion reached by the Europe Cement and Cementownia tribunals that, as a matter of principle, satisfaction is the proper remediation for moral damages suffered by a State. The issue nevertheless raises several unprecedented questions that merit further analysis. It is important to distinguish between an investor's actions taking place in the context of its investment in the host State (a) and misconduct arising in the context of arbitration proceedings (b).

(a) Investor's misconduct taking place in the context of its investment. As mentioned above, there are certain kinds of internationally wrongful acts that directly affect a State in its honour and dignity and result in moral damages which can be remediated by satisfaction. What characterizes these specific wrongs? Wittich mentions that these 'violations are characterized by the criterion of the seriousness of the wrongful act, which lies either in the importance of the good or values protected by the norm breached or in aggravating circumstances such as the degree of fault, or both' ${ }^{185}$ For instance, the breach of certain of obligations will always entail moral damages because they are 'considered fundamental either because they flow directly from the quality of the State as a person under international law and are the 'public manifestation' of its status as a sovereign State, or (..) because these rules are indispensable for the maintenance of good relations between States. ${ }^{186}$ Wittich also mentions that 'the occurrence of non-material damage to the State is restricted to deliberate breaches of international law'. ${ }^{187}$ Breaches of law typically giving rise to any moral damage to a State will normally occur in the context of State-to-State relationship.

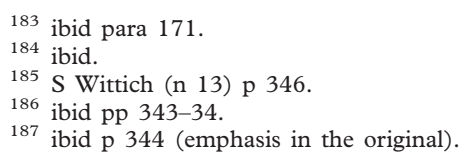


In fact, it is difficult to think of any situation where a foreign investor could intentionally commit a breach of a fundamental rule of international law damaging the host State's honour and dignity. The reading of the following list of typical breaches referred to in the ILC Commentaries makes it all the more clear that they are generally inapplicable in the context of an investor-State relationship: 'insults to the symbols of the State, such as the national flag, violations of sovereignty or territorial integrity, attacks on ships or aircraft, ill-treatment of or deliberate attacks on heads of State or Government or diplomatic or consular representatives or other protected persons and violations of the premises of embassies or consulates or of the residences of members of the mission. ${ }^{188}$ Most of these circumstances simply do not arise in the context of investment. ${ }^{189}$ At most, one cannot discard the possibility that a foreign investor could 'insult' symbols of the host State, its government, head of States, etc.

Recent ICSID cases show, however, that it is not uncommon for foreign investors to engage in different kinds of misconduct when doing business abroad. ${ }^{190}$ Tribunals have held that based on the general concept of 'ordre public international,' they lack jurisdiction (or that a claim is inadmissible) when faced with the illegal conduct of an investor, such as misrepresentations made by the claimant ${ }^{191}$ or bribery/corruption. ${ }^{192}$ In Gustav $F W$ Hamester $G m b H$ \& $C o \quad K G \vee$ Ghana, the Tribunal summarized the situation as follows: 'An investment will not be protected if it has been created in violation of national or international principles of good faith; by way of corruption, fraud, or deceitful conduct; or if its creation itself constitutes a misuse of the system of international investment protection under the ICSID Convention. It will also not be protected if it is made in violation of the host State's law. ${ }^{193}$ It is doubtful that any of these acts of misconduct, however serious they may be, can be considered as truly affecting the host State's honour and dignity causing any kind of moral damage. One exception may be human rights violations committed by an investor. ${ }^{194}$ In sum, situations where an investor could commit a breach of law resulting in any sort of moral damage for the host State will be very rare.

188 ILC Commentaries (n 11) pp 264-65.

189 Thus, how can a foreign investor, already admitted in the country, breach the territorial integrity of the host State? Similarly, how can an investor doing business in the host State of the investment attack the diplomatic representative or violate the premises of the embassy of that State abroad?

190 A Newcombe, 'Investor Misconduct in Investment Treaty Arbitration', in A De Mestral (ed) Improving International Investment Treaties: Negotiation, Substantive Obligations and Dispute Resolution (Routledge 2012) (forthcoming).

191 Plama Consortium Limited v Bulgaria, ICSID (Case ARB/03/24) Award, 27 August 2008.

192 World Duty Free Company Limited v Kenya, ICSID (Case ARB/00/7) Award, 4 October 2006.

193 Gustav F W Hamester GmbH \& Co KG v Republic of Ghana, ICSID (Case ARB/07/24) Award, 10 June 2010, para 123.

194 Phoenix Action Ltd. v Czech Republic, ICSID (Case ARB (AF)/06/5) Award, 15 April 2009, para 78, where the Tribunal expressed the view that protection 'should not be granted to investments made in violation of the most fundamental rules of protection of human rights, like investments made in pursuance of torture or genocide or in support of slavery or trafficking of human organs'. 
In any event, even if such a situation would occur, it is submitted that an arbitral tribunal would most probably not have jurisdiction over the complaint filed by the State. A series of recent arbitral awards in the context of disputes between foreign investors and States show that in general, tribunals have jurisdiction to award compensation for moral damages suffered by individuals and corporations. ${ }^{195}$ As clearly stated by the Cementownia Tribunal, nothing in the ICSID Convention 'prevents an arbitral tribunal from granting moral damages. ${ }^{196}$ The present author is also unaware of any BIT that expressly prohibits arbitral tribunals from awarding compensation for moral damages. ${ }^{197}$ But does a tribunal have jurisdiction under a BIT over a claim submitted by $a$ respondent State for compensation for moral damages?

Under the vast majority of BITs, arbitral tribunals only have jurisdiction to adjudicate claims brought by investors, and not those submitted by the host State of the investment. ${ }^{198}$ Under these treaties, it is generally recognized that the tribunal's jurisdiction over a claim brought by an investor does not imply jurisdiction over a counterclaim submitted by the respondent State. ${ }^{199}$ Under these treaties, the respondent State will therefore not be entitled to submit a counterclaim for moral damages. In any event, States are faced with another hurtle. Arbitral tribunals will typically only have jurisdiction to adjudicate disputes originating from alleged breaches of a treaty provision. ${ }^{200}$ Thus, in order to bring a claim under a BIT, the respondent State must argue that the investor has breached one of its rights contained in that treaty. In their present form, BITs are asymmetrical (and imbalanced) insofar as investors are being accorded substantive rights (without being subject to any specific obligations) while States only have obligations. ${ }^{201}$ In other words, an investor simply cannot breach any rights of the host State under these treaties since no such rights exist. This typical feature of the vast majority of BITs clearly bars respondent States from claiming any compensation for moral damages in proceedings under these treaties.

195 P Dumberry (n 2) p 274; B Sabahi (n 105) p 257; E Gaillard, 'Chronique des sentence arbitrales CIRDI' (2009) 136 Journal Du Droit International 354.

196 Cementownia (n 7) para 169. See also: Desert Line (n 3) para 289: 'even if investment treaties primarily aim at protecting property and economic values, they do not exclude, as such, that a party may, in exceptional circumstances, ask for compensation for moral damages. It is generally accepted in most legal systems that moral damages may also be recovered besides pure economic damages. There are indeed no reasons to exclude them'.

${ }_{197}$ Some BITs prevent arbitral tribunals from ordering a disputing party to pay punitive damages: For instance, Art 1135(3) of NAFTA; Art 44(3) of the Canada Model BIT; Art 44(3) of the Canada-Peru BIT; Art 34(3) of the US Model BIT.

${ }_{198}$ For instance, NAFTA Art 1116(1)a.

199 HE Veenstra-Kjos, 'Counterclaims by Host States in Investment Treaty Arbitration' (2007) Transnational Dispute Management 4, at p 9 et seq.; C Schreuer, The ICSID Convention: A Commentary (CUP 2009) 754.

200 A good example is NAFTA Art 1116(1)a): 'An investor of a Party may submit to arbitration under this Section a claim that another Party has breached an obligation under [NAFTA]'.

${ }^{201}$ This question is addressed in P Dumberry, 'Corporate Investors' International Legal Personality and their Accountability for Human Rights Violations under Investment Treaties', in A De Mestral (n 190). 
There are nonetheless some BITs that expressly allow States to institute arbitral proceedings. ${ }^{202}$ These treaties generally contain broadly-worded dispute resolution clauses referring, for instance, to 'disputes with respect to investments', 'all disputes', 'any disputes' or 'any legal disputes'. ${ }^{203}$ Such a clause would, in principle, allow a State to bring forward to a tribunal a claim that the investor breached its rights. However, since BITs do not contain any such State rights, reference will have to be made to rights existing under, for instance, a State contract. ${ }^{204}$ It is only once a respondent State has passed these successive hurdles that it should be allowed, as a matter of principle, to file a counterclaim seeking compensation for any moral damages suffered. Yet again, even in those favourable circumstances where a tribunal would have jurisdiction over a counterclaim, 'there is still another obstacle to overcome: the requirement of the 'connexity' between the primary claim and the counterclaim. ${ }^{, 205}$ Thus, under Article 46 of the ICSID Convention, a tribunal 'shall determine any incidental claims or counterclaims arising directly out of the subject-matter of the dispute.' A tribunal may ultimately reject a counterclaim on the ground that it is 'disconnected' with the claim submitted by the investor and, therefore, outside the scope of arbitration. In sum, the possibility for States to claim compensation for moral damages under BITs is quite limited.

In the (rare) event that the commission of a wrongful act by an investor would cause any moral damages to the host State and in the (also rare) event that a tribunal constituted under a BIT would have jurisdiction over such a claim, we submit that the most appropriate form of satisfaction to remedy any such damages would be a declaration of wrongfulness by the tribunal. Thus, the mere fact that such a declaration is expressed (most often publically) by an international tribunal constitutes in itself a form of satisfaction to the injured State. ${ }^{206}$ The function of a judicial declaration of the unlawful character of an act is certainly an appropriate form of reparation for the 'legal' damage component of any moral damage suffered by a State insofar as it 'wip[es] out one of the most serious consequences of an internationally wrongful act, namely, the weakening of the obligation-and of the corresponding right - which has been breached' ${ }^{207}$

Other forms of satisfaction, such as expression of regrets or official apologies, seem better-suited for a State-to-State relationship. Thus, one can hardly see how apologies made by a foreign investor could truly remediate any damage

\footnotetext{
${ }^{202}$ H Bubrowski, 'Counterclaims', in A De Mestral (n 190) 11 (of the paper version) (forthcoming) refers to Art 7(2) of the French Model BIT, Art 10(2) of the German Model BIT and many BITs entered into by the United Kingdom.

203 ibid p 8 (of the paper version).

204 ibid

205 ibid p 16 (of the paper version); C Schreuer, The ICSID Convention: A Commentary, p 743.

206 L Migliorino (n 48) p 72.

207 E Fasoli (n 37) p 184, for whom the function of a declaration is 'confirming and enhancing the legally binding force of the international rule violated'.
} 
done to a State's honour and dignity. As mentioned above, awarding monetary compensation as a form of 'pecuniary satisfaction' to the host State, should be limited to those situations involving 'gross infringement of the rights of the injured State. ${ }^{208}$ Instances of serious breaches of the most fundamental rules of international law, such as those which occurred in the Rainbow Warrior case, seem unlikely to ever arise in the investment context.

(b) Investor's misconduct arising in the context of arbitration proceedings. The Europe Cement and Cementownia cases involved allegations of moral damages suffered by a respondent State in the context of arbitral proceedings commenced by an investor. Authors have recently argued that 'under certain limited and exceptional circumstances (...) there may be good reasons why a respondent state may be entitled to an award of moral damages in addition to a declaratory judgment and attorney fees and costs. ${ }^{209}$ For them, such an award of monetary compensation may be an appropriate form of satisfaction. ${ }^{210}$ This proposal is based on the claim that 'when an investor commences an ICSID arbitration against a respondent state and the investor ultimately loses, the state may have a credible argument that its 'investment reputation' has been unfairly tarnished'. ${ }^{211}$ The authors admit that a respondent State's reputation 'may ultimately be vindicated and restored at the conclusion of an arbitration and upon the issuance of a favourable award. ${ }^{212}$ For them, however, this does not solve the problem of the significant amount of time (said to be 4 years on average $)^{213}$ that usually passes between the initial request for ICSID arbitration and the issuance of a final award. During that period, they argued that foreign investors may decide not to invest in that country precisely because of a pending arbitration claim. ${ }^{214}$ In order to recover such losses, tribunals should consider awarding moral damages to a prevailing respondent State in

208 Article 45(2) of the 1996 Draft of the ILC Articles. C Domincé (n 20) p 362 reserves this form of satisfaction to particularly grave breaches of international law ('on peut affirmer assurément que dans des circonstances où la violation du droit international est particulièrement grave il paraît souhaitable que le tribunal ne se borne pas à condamner les comportements illicites, mais prescrive en outre une autre mesure de satisfaction, sous la forme, notamment, du versement d'une somme d'argent. Ce n'est sans doute pas fréquent, mais lorsque l'honneur, la dignité, d'un État sont atteint, les circonstances ici évoquées pourraient le justifier'). See also: C Gray (n 19) pp 33-34.

${ }^{209}$ MT Parish and others (n 25) p 236 (emphasis in the original).

210 ibid p 239.

211 ibid.

212 ibid p 237.

213 ibid.

214 ibid p 238 ('it does seem prima facie plausible that actions such as the filing of the Cementownia and Europe Cement cases may have tarnished Turkey's investment reputation to some degree. Publicity surrounding the expropriation of assets may cause prospective investors to think twice about a territory, or to channel their investment funds elsewhere. The number of factors that determine foreign investment flow will always be myriad and complex, so it may almost never be possible to precisely determine the quantity of investment lost by reason of a discrete act of filing a false ICSID claim. But it would be naïve to conclude that because of the density of causal factors, ICSID filings have no effect upon foreign investment flows.'). 
'particularly egregious cases' where 'a claim is vexatious or has been brought fraudulently or in bad faith., 215

In our view, there are many shortcomings with the proposition advanced by these authors. The first obvious one concerns jurisdiction. As mentioned above, under the vast majority of BITs, respondent States are simply barred from submitting any counterclaim for moral damages, even for damages arising during arbitration proceedings. ${ }^{216}$ This is precisely the conclusion reached by the Tribunal in Limited Liability Company AMTO $v$ Ukraine. $^{217}$ In this case, Ukraine submitted a counterclaim claiming, inter alia, compensation in the amount of $€ 25,000$ for 'non-material injury' for its damaged reputation resulting from 'unfounded allegations' raised by the investor in the proceedings about the collusion between two Ukrainian State-owned companies. ${ }^{218}$ The Tribunal dismissed the claim on the ground that it did not have jurisdiction over counterclaim under the Energy Charter Treaty: ${ }^{219}$

The jurisdiction of an Arbitral Tribunal over a State party counterclaim under an investment treaty depends upon the terms of the dispute resolution provisions of the treaty, the nature of the counterclaim, and the relationship of the counterclaims with the claims in the arbitration. Article 26(6) ECT provides that the applicable law to an ECT dispute is the Treaty itself and 'the applicable rules and principles of international law'. The Respondent has not presented any basis in this applicable law for a claim of non-material injury to reputation based on the allegations made before an Arbitral Tribunal. Accordingly, the Arbitral Tribunal finds that there is no basis for a counterclaim of this nature and it is accordingly dismissed. ${ }^{220}$

The proposition put forward by the authors mentioned above also suffers from other shortcomings. There is no concrete evidence supporting the assertion made by Turkey in the Europe Cement case that a country's 'investment reputation' is tarnished by the simple fact that an investor filed an (ultimately unsuccessful) frivolous arbitration claim. ${ }^{221}$ According to UNCTAD, the total number of known investor-state cases at the end of 2009 (357) includes an impressive 81 different States acting as respondents, including no less than 17 developed countries with both Canada and the United States at the top of the list (both are respondent in 14 cases each). ${ }^{22}$ The authors do not bring

215 ibid p 238

216 ibid pp 241-2 admitting this limitation.

217 Limited Liability Company AMTO v Ukraine (n 8).

218 ibid paras 35, 116. The Tribunal further explained the nature of the allegations as follows: 'the Respondent states that the Claimant has irresponsibly and insistently disseminated to the SCC Institute and to the Arbitral Tribunal untrue information about collusion between two state-owned entities, with the implication that Ukraine was involved. The Respondent considers that 'such dissemination does not deviate very much from libel'.' (para 117).

219 Article 26 of the Treaty contains a narrow dispute resolution clause only allowing claims from investors arising solely from treaty violation.

220 Award, para 118.

221 Europe Cement (n 6) para 177. See also Cementownia (n 7) para 165.

222 UNCTAD, Latest Developments in Investor-State Dispute Settlement, IIA Issues Note No 1 (2010), p 2 . 
forward any evidence that the 'reputation' of these 81 countries has been somehow affected by these claims, about half of which will ultimately be unsuccessful. ${ }^{223}$ Moreover, the authors do not provide conclusive evidence showing that the filing of an investment claims results in any financial losses for the respondent State. ${ }^{24}$ In our view, one of the only cases where the 'investment reputation' of a State will truly be tarnished is in the (rare) event it simply refuses to pay the investor the amount allocated by a tribunal in a winning award. ${ }^{225}$

Essentially, it can be argued that purported tarnished reputation and unproven losses of investments cannot be the foundation for allowing tribunals to award compensation for moral damages to respondent States in the context of arbitration proceedings instituted by an investor. This is the case even when the investor's claim is frivolous, baseless and ultimately unsuccessful. By entering into a BIT, a State knows quite well that it may be the object of an arbitration claim (even a frivolous one). Being a respondent in an investment case is simply part of the deal under any investment treaty. It is certainly not a blow to one State's honour or dignity. The reputation and international standing of a State is simply unaffected by the mere fact of its participation in arbitration proceedings under a BIT. This is true even in the context of baseless claims made in bad faith. This is the conclusion reached by the ad hoc tribunal in the above-mentioned dispute between Italy and Cuba. ${ }^{226}$ Cuba did not suffer any sort of moral damages by simply being a respondent in proceedings commenced by Italy under a BIT on behalf of its national investors. The Tribunal only went so far as to mention that 'abusive' proceedings started by a State could be illegal and would cause some form of damages. The Tribunal did not, however, indicate under which circumstances the exercise of such right by a State under a BIT could be deemed 'abusive', nor did it explain what type of damages would result. ${ }^{227}$

In fact, it is difficult to conceive of any circumstances where a State would suffer from any moral damages in arbitration proceedings. In the (unlikely) event that such damages were to exist, it is submitted that a declaration of wrongfulness by the tribunal should be an appropriate form of satisfaction.

\footnotetext{
223 ibid p 3, indicating that by the end of 2009, 164 cases had been brought to conclusion and that $38 \%$ of these cases were decided in favour of the State, $29 \%$ in favour of the investor, and that $34 \%$ were settled.

${ }^{224}$ MT Parish and others (n 25) p 236. In fact, they admit that the research studies they refer to reach opposite conclusions on the actual effect of arbitration filing on foreign investment flows.

${ }^{225}$ For instance, Zimbabwe recently refused to pay investors an ICSID award in the amount of $€ 8.2$ million: Funnekoter et al v Zimbabwe, ICSID (Case ARB/05/06) Award, 22 April 2009.

${ }_{226}$ Republique d'Italie v Republique de Cuba (n 151) para 254.

227 ibid para 254: 'les dispositions pertinentes de l'Art 10 de l'Accord de 1993 confèrent à chacune des parties contractantes le droit de soumettre à l'arbitrage les litiges relatifs à l'interprétation et à l'application de l'Accord. A moins qu'il ne soit abusif, l'exercice d'un tel droit ne peut être illicite et donc causer un préjudice donnant lieu à réparation. Bien que la République d'Italie succombe dans toutes ses demandes, le Tribunal arbitral n'estime pas que son droit de recourir à l'arbitrage selon les dispositions de l'Accord 1993 a été abusive. La demande reconventionnelle de la République de Cuba est donc rejetée'.
} 
In this context, Turkey and Ukraine's recent requests for monetary compensation, as a form of satisfaction, to remediate alleged moral damages are quite surprising. ${ }^{228}$ This is because, States are generally reluctant in international law to ask a tribunal to somehow quantify any moral injury suffered. ${ }^{229}$ As explained by the Umpire of the Italy-Venezuela Commission in the 1903 Stevenson case, ' $[\mathrm{t}$ ] have measured in money by a third and different party the indignity put upon one's flag or brought upon one's country is something to which nations do not ordinarily consent. ${ }^{230}$

Recent litigation cases between States shows that they prefer instead to request an apology from the responsible State or, more frequently, to ask a tribunal to issue a declaration of wrongfulness. ${ }^{231}$ This point is well illustrated by three recent ICJ cases where plaintiff States did not ask the Court an award of compensation for moral damages suffered even though the facts of each case warranted such a request. ${ }^{232}$ There is thus no doubt that an arrest warrant issued by Belgium against the Congolese Foreign Minister, contrary to basic rules of diplomatic immunity, caused Congo a moral damage. ${ }^{233}$ In fact, Congo explicitly acknowledged having suffered such moral injury, but nevertheless only requested a declaration of wrongfulness by the Court. ${ }^{234}$ The Bosnian genocide case $\mathrm{e}^{235}$ the LaGrand case ${ }^{236}$ and the Rainbow Warrior case also confirm this trend. ${ }^{237}$

Why are States not claiming monetary compensation as a form of satisfaction when they clearly suffer a moral damage? Dominicé convincingly argues that it is the injured State's own dignity and honor that explain

\footnotetext{
228 In fact, such requests may be explained based on opportunistic grounds more than anything else. After the recent groundbreaking Desert Line (n 3) Award in 2008, it may be that these States simply hoped that the tribunals would jump on the wagon and award monetary compensation to respondent States as well as investors.

229 S Wittich (n 13) p 367.

230 Stevenson Case (on merits), UNRIAA, IX pp 494-510, at p 506.

231 S Wittich (n 13) p 367 ('it would seem that where the responsible State has consented to judicial or arbitral dispute settlement, the State having suffered direct non-material damages will usually be content with a declaration of the wrongfulness which it considers sufficient to make good the non-material damage it has suffered.').

232 S Wittich (n 13) p 339.

233 Arrest Warrant Case (n 52) para 75.

234 ibid para 72: 'a formal finding by the Court of the unlawfulness of the [warrant] constitutes an appropriate form of satisfaction providing reparation for the consequent moral injury to the Democratic Republic of Congo.'

${ }^{235}$ The Application of the Convention on the Prevention and Punishment of the Crime of Genocide (n 53) para 462. A Gattini, 'Breach of the Obligation to Prevent and Reparation Thereof in the ICJ's Genocide Judgment' (2007) 18 European Journal of International Law 2007, indicates that even though Bosnia had not asked for any compensation, but only for a declaration of wrongfulness, 'in the light of the exceptional gravity of the crimes under consideration, the Court could have shown more creativity and sensitivity with regard to the 'non-material damage suffered by the surviving heirs or successors [of the victims] and their dependants', as Bosnia had requested' (p 711).

${ }^{236}$ LaGrand case (Germany v United States), ICf Rep 2001, para 128. Clearly the execution of a German national by the United States in complete disregard of a binding order on provisional measures issued by the ICJ constitutes an affront to the honour and dignity of Germany. Yet, Germany did not request any monetary compensation.

237 Rainbow Warrior (n 91) In that case, New Zealand had argued that the attack by French secret service agents was 'a serious violation of basic norms of international law' and 'a serious violation of [its] sovereignty', but did not request any compensation for such moral injury.
} 
such reluctance. ${ }^{238}$ Thus, a symbolic (and typically very small) amount of money could, in any event, never fully compensate for the humiliation suffered. Why then bother with such a futile request? In other words, a nation that has already gone through the public humiliation of seeing its honor and dignity breached by another State on the world stage, is typically proud enough not to ask a tribunal to put a number on such elusive injury. In our view, if there is anything such as State 'pride' it should, a fortiori, lead States involved in arbitration proceedings with foreign investors not to ask tribunals for any such monetary compensation for moral injury. A sovereign State should naturally be reluctant to formally, and publically, even admit having been humiliated and having suffered injury to its very honor and dignity at the hand of a foreign investor doing business within its borders. This is because corporations, no matter how large and powerful they may be in the modern context of globalization, are simply not co-equal with States under international law. ${ }^{239}$ It is noteworthy that in the entirely different context of State-to-State arbitration proceedings between Italy and Cuba, where the parties involved are both sovereign and equal States, the latter only requested the Tribunal to condemn the former to officially 'withdrawn' its allegations of breach of BIT. Cuba did not claim to the Tribunal any compensation as a form of satisfaction for the alleged moral damages suffered by the mere fact of being respondent in these proceedings.

In our view, solutions (other than satisfaction) already exist to address the problems arising from the submission of frivolous claims by investors. In response to this growing concern, ICSID amended in 2006 its Arbitration Rules to allow tribunals to dismiss at an early stage any clam that is 'manifestly without legal merit. ${ }^{240}$ Tribunals have recently rejected two claims on that basis. ${ }^{241}$ This new mechanism will serve as a gatekeeper to reduce the

${ }^{238}$ C Dominicé (n 20) p 363 ('il est utile de s'interroger sur le motif des incitations de l'État à conclure à l'attribution d'une compensation monétaire. De la part de l'État qui se plaint d'une grossière violation de ses droits, qui ressent une forte atteinte à sa dignité, n'est-ce pas finalement un peu petit, à la rigueur même mesquin, de solliciter l'octroi d'une somme d'argent, qui de toute manière ne saurait avoir aucunes communes mesures avec le préjudice immatériel souffert? N'y a-t-il pas une sensible inéquation entre, d'une part, un grave préjudice se situant sur le plan de l'honneur, de la dignité, et, d'autre part, une compensation se situant au niveau matériel d'une somme d'argent peu significative? Elle a sans doute valeur de symbole, mais est-ce suffisant? On tombe dans une sorte d'impasse, car d'un côté l'on éprouve le besoin, en certaines circonstances, d'élargir la satisfaction en y incluant un autre élément à côté de la condamnation verbale et l'on pense à une compensation monétaire, mais on ressent de l'autre côté que celle-ci paraît peu adéquate, petite, et d'autant plus qu'il s'agit de transferts financiers forcément peu significatifs d'un budget public à un autre budget public, dans un total anonymat").

${ }^{239}$ States are primary subjects of international law. This remains the case even in the specific context of a BIT where it can be argued that corporations possess a limited international legal personality. See P Dumberry, 'L'entreprise, sujet de droit international? Retour sur la question à la lumière des développements récents du droit international des investissements' (2004) 108 Revue Générale De Droit International Public 103-22 ; P Dumberry and E Labelle Eastaugh, 'Non-State Actors in International Investment Law: The Legal Personality of Corporations and NGOs in the Context of Investor-State Arbitration', in J d'Aspremont (ed), Participants in the International Legal System: Multiples Perspectives on Non-State Actors in International Law. (Routledge-Cavendish 2011) 360-71.

${ }_{240}$ Para 5 and 6 of Rule 41 of the Arbitration Rules.

241 Global Trading Resource Corp v Ukraine, ICSID (Case ARB/09/11) Award, 1 December 2010; RSM Prod Corp v Grenada, ICSID (Case ARB/10/6) Award, 10 December 2010. 
likeliness of frivolous claims going any further than the initial stage of the proceedings. In our view, the real damage suffered by a respondent State subject to a vexatious and bad faith claim is not so much to its intangible 'investment reputation' but the considerable amount of money, time and resources it must spend in responding to such frivolous allegations. A respondent State's defence is, indeed, very expensive whether or not the allegations are baseless. Early dismissals of frivolous claims will, of course, have a major beneficial financial impact for respondent States. These financial concerns can also be properly addressed by tribunals by ordering the plaintiff to pay the respondent State's arbitration costs as well as the attorney and expenses related to the proceedings. This is, indeed, the approach recently adopted by the Europe Cement and Cementownia tribunals (in the amount of US $\$ 4$ million and US $\$ 5.6$ million, respectively). As rightly observed by the Cementownia Tribunal, 'in case of an abuse of rights, ICSID tribunals can award costs against parties as a sanction against what they see as dilatory or otherwise improper conduct in the proceedings'. ${ }^{242}$ Hopefully, this approach will be followed by future tribunals.

\section{Conclusion}

Our analysis of case law has shown that under international law, monetary compensation is the appropriate remedy for moral damages affecting an individual. State practice and case law also demonstrate that satisfaction is the proper mean of reparation for non-material injury caused to a State directly. As explained by Vicuna in the Letelier case, 'the question of satisfaction arises not in relation to individuals but in relation to another State which could have been offended by a wrongful act. ${ }^{, 243}$ In at least one case (Rainbow Warrior) a tribunal has awarded monetary compensation, as a specific form of satisfaction, to remedy the moral damages suffered directly by a State.

The situation is no different in the specific field of international investment law. Our analysis of recent investor-State case law shows that monetary compensation remains the appropriate remedy for moral damages affecting an individual or a corporation. Satisfaction is not the proper method of remediation in this context. The reasoning of the tribunals in the recent ICSID cases of Europe Cement and Cementownia rightly suggests that satisfaction, in the form of a declaration of wrongfulness, would be the most appropriate form of reparation to remedy any moral damage suffered by a respondent State. The issue of moral damages suffered by a State in the context of international investment law is, however, unlikely to frequently arise. Moreover, under most BITs, arbitral tribunals will simply not have jurisdiction over any moral damages allegations raised by a respondent State.

242 Cementownia (n 7) para 158.

243 Letelier (n 29) Concurring Opinion of Vicuna, pp 16-7. 